\title{
ARTICLE
}

\section{THE CASE FOR RESURRECTING THE FTC ACT'S PENALTY OFFENSE AUTHORITY}

\author{
ROHIT CHOPRA ${ }^{\dagger} \&$ SAMUEL A.A. LEVINE ${ }^{\dagger \dagger}$
}

On April 22, 2021, the Supreme Court unanimously ruled that the Federal Trade Commission cannot continue to seek monetary relief from wrongdoers through $\$ 13(b)$ of the Federal Trade Commission (FTC) Act-the authority predominantly relied on to challenge lawbreaking in federal court.

This news followed a string of mounting criticisms in recent years that have undermined public confidence in the Agency. A decade ago, after the FTC largely stood idle against abuses by subprime lenders, Congress stripped the Agency of key authorities over the financial sector. Today, concerns about the adequacy of the FTC's antitrust enforcement and about its effectiveness as a privacy and data protection watchdog are once again raising questions about whether the FTC can protect the public from digital abuses.

Today's crisis of confidence can be traced back to the 1980s. During that decade, Chairman James C. Miller III and his lieutenants took control of the Commission, and professed faith in the idea that markets could be trusted to regulate themselves. They supported crippling cuts to the Agency's budget and headcount, while shifting the Commission's focus away from combating corporate abuse. They also shelved the Commission's strongest tools to deter lawbreaking, turning instead to $\S 13(b)$, the authority now limited by the Supreme Court. While $\S 13(b)$ was an important tool,

$\dagger$ Director, Consumer Financial Protection Bureau. The views expressed here are Director Chopra's and do not necessarily reflect those of the Federal Trade Commission, any other individual Commissioner, or the Consumer Financial Protection Bureau. Director Chopra served as a Commissioner of the Federal Trade Commission from May 2018 to October 2021.

$\dagger \dagger$ Director, Bureau of Consumer Protection, Federal Trade Commission. The views expressed here are Director Levine's and do not necessarily reflect those of the Federal Trade Commission or the Bureau of Consumer Protection. The authors wish to thank Maria B. Bazan for her invaluable assistance. In addition, we are grateful to David Vladeck, Neil Averitt, Bonnie Patten, Luke Herrine, and staff at the FTC for their thoughtful engagement and comments. 
it did not allow the Commission to actually seek penalties against wrongdoing, and it is best suited to one-off enforcement rather than ensuring compliance market-wide. This has meant that for large firms and other established corporate actors, breaking the law can be a good bet.

In this Article, we detail why the Agency should resurrect one of the key authorities abandoned in the 1980s: $\$ 5(m)(1)(B)$ of the FTC Act, the Penalty Offense Authority. The Penalty Offense Authority is a unique tool in commercial regulation. Typically, first-time offenses involving unfair or deceptive practices do not lead to civil penalties. However, if the Commission formally condemns these practices in a cease-and-desist order, they can become what we call "Penalty Offenses." Other parties that commit these offenses with knowledge that they have been condemned by the Commission face financial penalties that can add up to a multiple of their illegal profits, rather than a fraction.

Using this authority, the Commission can substantially increase deterrence and reduce litigation risk by noticing whole industries of Penalty Offenses, exposing violators to significant civil penalties, while helping to ensure fairness for honest firms. This would dramatically improve the FTC's effectiveness relative to relying exclusively on equitable monetary relief and no-money cease and desist orders.

We demonstrate in this Article that in a number of key areas, including urgent concerns like online disinformation, the Commission can deploy the Penalty Offense Authority immediately. This can increase deterrence, since firms will pay a significant price for engaging in unfair or deceptive practices previously condemned by the Commission. We also outline how the Commission can deploy this authority to combat emerging harms, including illegal targeted marketing and deceptive data harvesting.

We close with a call for a broader rethinking of the Commission's approach to combatting corporate misconduct. By inventorying its existing tools and deploying them strategically, the Commission can begin to turn the page on its checkered record and regain the public's confidence.

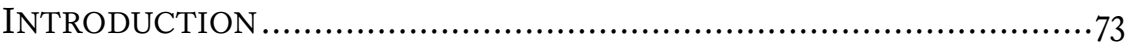

I. OVERVIEW OF THE FEDERAL TRADE COMMISSION'S

AUTHORITIES AND ITS HEAVY RELIANCE ON $\S 13(\mathrm{~B}) \ldots \ldots \ldots \ldots \ldots . . . . . . .79$

A. Overview of Remedies Available to the Commission ...........................80

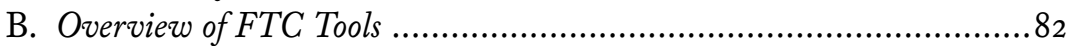

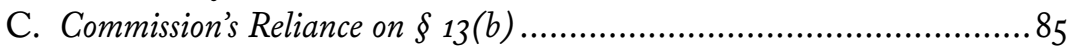

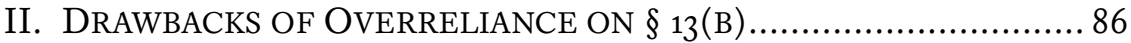

A. Hard-to-Quantify Harm ........................................................... 87

B. Harm that Exceeds Direct Gains or Losses ....................................... 91

III. Advantages OF THE PENALTy OfFEnse Authority

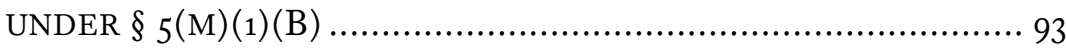

A. Background on the Penalty Offense Authority ....................................93 
B. Key Advantages of the Penalty Offense Authority over $\S 13(b)$.............98

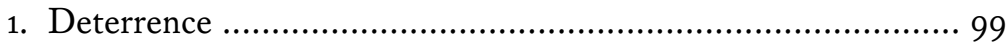

2. Lessened Litigation Risk ................................................. 102

3. Market-wide Impact ........................................................103

IV. Potential Applications of the PEnAlty OfFEnse

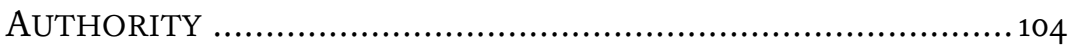

A. For-Profit College Fraud ......................................................... 104

B. False Earnings Claims Targeting Workers........................................ 108

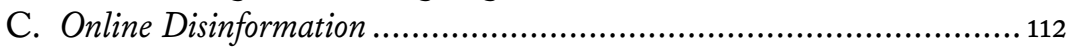

D. Deceptive Data Harvesting ......................................................... 115

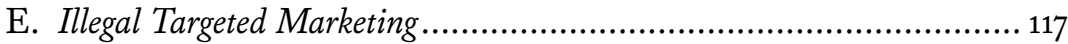

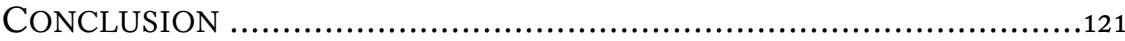

\section{INTRODUCTION}

The Supreme Court recently ruled that the Federal Trade Commission cannot seek monetary relief in federal court through $\S 13$ (b) of the FTC Act. ${ }^{1}$ This decision has been described as an existential threat to the FTC's mission of promoting fair markets. ${ }^{2}$ That is because even though the Commission has many other powers, $\S 13(\mathrm{~b})$ is the primary means by which the Agency brings enforcement actions in federal court. This singular reliance is recent, and its origins are ideological.

In the 1980 os, the FTC fundamentally reoriented its consumer protection mission, moving away from combatting market-wide abuses by major corporations and toward a heavy focus on shutting down fly-by-night criminal scams through civil law enforcement actions. ${ }^{3}$ At the time, the leading proponent of this shift was James C. Miller III, who became Chairman of the Commission in 1981.4

Miller arrived following a moment of crisis for the Agency, which had been derided as the "National Nanny" when it sought to crack down on child-

1 AMG Cap. Mgmt., LLC v. FTC, 141 S. Ct. 1341, 1344 (2021) [hereinafter AMG v. FTC].

2 See, e.g., Brent Kendall, Supreme Court Cuts Federal Trade Commission Powers to Recover Ill-Gotten Gains, WALL ST. J., https://www.wsj.com/articles/supreme-court-cuts-federal-trade-commission-powers-torecover-ill-gotten-gains-11619102862 (Apr. 22, 2015, 5:52 PM) [https://perma.cc/FHP8-ZGY2].

3 See Miles W. Kirkpatrick, Report of the American Bar Association Section of Antitrust Law Special Committee to Study the Role of the Federal Trade Commission, 58 ANTITRUST L.J. 43, 70-71, 81 (1989) (noting that the FTC was devoting an increasing share of resources to challenging outright fraud, while facing criticism for having "failed to bring cases of consequence"); Neil W. Averitt \& Terry Calvani, The Role of the FTC in American Society, 39 OKLA. L. REV. 39, 48 (1986) (noting the Reaganera FTC's focus on "hard-core fraud").

4 See generally Luke Herrine, The Folklore of Unfairness, 96 N.Y.U. L. REV. 431 (2021). 
directed advertising. ${ }^{5}$ For Miller, this crisis was an opportunity to not only reverse rulemakings but also disarm the administrative state. During his confirmation process before joining the Commission, he argued that the FTC should move away from rulemaking and toward efforts to "reinforce market forces," while shifting enforcement resources to challenging small-scale criminal fraud rather than misconduct by established corporate actors. ${ }^{6}$ Miller was also highly skeptical of the Commission's authority to prohibit unfair practices, and vowed to rein it in. ${ }^{7} \mathrm{He}$ and his lieutenants instead espoused the view that markets could largely be trusted to regulate themselves. ${ }^{8}$

Once confirmed, Miller moved quickly to dismantle the Agency and upend its mission. So aggressive were these changes that they drew bipartisan opposition, ${ }^{9}$ but they largely succeeded. Miller supported dramatic staffing reductions, and by the end of the 1980s, the Agency's headcount had been halved. ${ }^{10} \mathrm{He}$ opposed efforts to actively monitor markets, and in 1985 , the Commission announced that it would halt publication of its annual Line of Business Reports, cutting off a critical set of data.11 Under his watch, the number of rulemakings and enforcement actions plummeted, ${ }^{12}$ and the Agency adopted Policy Statements that limited its own authority to combat unfair and

$5 \mathrm{Id}$. at 503-04.

6 See Mark E. Budnitz, The FTC's Consumer Protection Program During the Miller Years: Lessons for Administrative Agency Structure and Operation, 46 CATH. U. L. REV. 371, 377-80 (1997) (explaining Miller's views during his nomination process).

$7 \mathrm{Id}$.

8 Miller believed that "the best consumer protection possible is provided by a well-functioning marketplace." JAMES C. MILlER III, THE ECONOMIST AS REFORMER: REVAMPING THE FTC, 1981-1985, at 9 (1989). During his confirmation hearings, he argued that the government should not intervene to protect "a few gullible people" from deception and suggested that challenging unfair practices would no longer be a priority for the Commission. See Budnitz, supra note 6, at 378-79.

9 For example, Republican Commissioner Patricia P. Bailey spoke out against changes to the Commission's deception standard. See FTC's Authority Over Deceptive Advertising: Hearing Before the Subcomm. for Consumers of the S. Comm. on Com., Sci., E Transp., 97th Cong. 53 (1982) (statement of Hon. Patricia P. Bailey, Comm'r, Federal Trade Commission) ("All of the proposals which have been advanced so far to alter the statute's language would substantially narrow the FTC's authority over deceptive practices."). Miller's efforts to close regional offices also drew bipartisan opposition. See Budnitz, supra note 6, at 387-90 (detailing the political controversy of Miller closing regional offices).

10 See FTC Appropriation and Full-Time Equivalent (FTE) History, FTC [hereinafter FTC Appropriation History], https://www.ftc.gov/about-ftc/bureaus-offices/office-executive-director/financialmanagement-office/ftc-appropriation [https://perma.cc/2XNM-YMB4] (showing a headcount change of full-time employees from 1,719 in 1980 to 894 in 1989).

11 See FTC, Bureau of Econ., Statistical Report: AnNual Line of Business REPORT 1977, at 1 (1985), https://www.ftc.gov/sites/default/files/documents/reports/u.s.federaltrade-commission-bureau-economics-annual-line-business-report-1977-statistical-report/231945.pdf [https://perma.cc/YK6H-A8R2] ("This is the last in a series of five Annual Line of Business Reports (ALBRs) to be published by the Commission ....").

12 See Budnitz, supra note 6, at 391-95 (describing the drop-off in enforcement cases under Miller's tenure); id. at 435-36 (describing the drop-off in rulemaking). 
deceptive practices. ${ }^{13}$ The cases that the Commission did bring increasingly targeted small-time scams rather than abuses by large corporate actors. ${ }^{14}$

Miller left the Commission in 1985, but the changes he wrought were longlasting. Although subsequent Commissions began to revive the use of unfairness and challenge corporate misconduct, ${ }^{15}$ the Commission's headcount remains far below what it was when Miller was appointed,16 the Policy Statements he

13 With respect to deception, the Commission announced that it would prosecute cases only if representations were likely to mislead reasonable consumers about a material fact, which limited the Agency's authority to combat more subtle misrepresentations or misrepresentations that harmed less sophisticated consumers. See Cliffdale Assocs., Inc., 103 F.T.C. 110, app. at 176 (1984)) ("[T]he Commission will find deception if there is a [material] representation, omission or practice that is likely to mislead the consumer acting reasonably in the circumstances, to the consumer's detriment."). This weakened standard drew bipartisan opposition from Congress, state attorneys general, and Miller's fellow commissioners. See Budnitz, supra note 6, at 396-404 (describing the controversy around Miller's redefinition of "deception"). Miller also sought to weaken the Commission's unfairness standard, and he urged Congress to amend the FTC Act to narrow the Agency's authority. Id. at 409. This effort did not initially succeed, but in 1984, the Commission formally appended to an opinion its Policy Statement on Unfairness, which stated that markets should be presumed to be "selfcorrecting." See Int'l Harvester Co., 104 F.T.C. 949, app. at 1072 (1984) ("Normally we expect the marketplace to be self-correcting, and we rely on consumer choice-the ability of individual consumers to make their own private purchasing decisions without regulatory intervention-to govern the market."). In a comment filed in early 2020, we detailed how the Commission's post-1980 unfairness standard-which has largely been rejected by other consumer protection enforcers-has hobbled FTC enforcement in the decades since. See FTC Comm'r Rohit Chopra, Comment Letter on Proposed Rule Defining Unfair or Deceptive Practices, 5-6 (May 28, 2020) [hereinafter Comment Before the Dep't of Transp.], https://www.regulations.gov/comment/DOT-OST-2019-0182-0225 [https://perma.cc/LW 3 C-Y6R6] (click "download").

14 See sources cited in supra note 3 and accompanying text.

15 For example, in 2012, the Commission used its unfairness authority to challenge lax data security practices by Wyndham Hotels. Press Release, FTC, FTC Files Complaint Against Wyndham Hotels for Failure to Protect Consumers' Personal Information (June 26, 2012), https://www.ftc.gov/news-events/press-releases/2012/06/ftc-files-complaint-against-wyndham-

hotels-failure-protect [https://perma.cc/DHS5-LSMJ]. That same year, it also sued a major apparel manufacturer for making unsubstantiated weight loss claims, returning $\$ 40$ million to consumers. See Press Release, FTC, Skechers Will Pay $\$ 40$ Million to Settle FTC Charges That It Deceived Consumers with Ads for "Toning Shoes" (May 16, 2012), https://www.ftc.gov/news-events/pressreleases/2012/05/skechers-will-pay-40-million-settle-ftc-charges-it-deceived

[https://perma.cc/B2TX-ABKN]. These cases show that $\S 13(\mathrm{~b})$ can be deployed to challenge misconduct by large corporations, but they also underscore the limits of the authority. Skechers compensated victims but paid no actual penalty, while Wyndham Hotels paid nothing at all. See FTC v. Skechers U.S.A., No. 12-01214, 2012 WL 1699432, at *10 (N.D. Ohio May 16, 2012) (specifying that no portion of the Skechers settlement constitutes "any fine, penalty, or punitive assessment"); Press Release, FTC, Wyndham Settles FTC Charges It Unfairly Placed Consumers' Payment Card Information at Risk (Dec. 9, 2015), https://www.ftc.gov/news-events/pressreleases/2015/12/wyndham-settles-ftc-charges-it-unfairly-placed-consumers-payment (settling with Wyndham without requiring payment).

16 See FTC Appropriation History, supra note 10. 
championed continue to restrict the Agency's authority, and combatting small scams remains the FTC's principal consumer protection priority. ${ }^{17}$

The Commission's track record since the 1980 s raises serious questions about the wisdom of Miller's ideological project. In key sectors of commerce, the FTC's post-1980 view that markets are self correcting has been proven wrong-sometimes disastrously. For example, the Commission's ideological opposition to deploying its unfairness authority prevented the Agency from challenging child-directed tobacco advertising in the early 1990s. ${ }^{18}$ While the Agency later tried to reverse itself under congressional pressure, it was ultimately action by state attorneys general- not the FTC, and not market forces - that halted these practices. ${ }^{19}$

During the run up to the mortgage meltdown, the FTC focused its financial enforcement efforts on small-scale fraud, rather than systemic failures. The FTC largely stood idle as "legitimate" lenders, like Countrywide and Ameriquest, tricked Americans into taking out subprime loans that were structured to fail. ${ }^{20}$ These unfair and deceptive practices "self-

17 See, e.g., Staying a Step Ahead: Fighting Back Against Scams Used to Defraud Americans: Hearing Before the Subcomm. on Consumer Protection, Prod. Safety, E Data Sec. of the S. Comm. on Com., Sci., $\Xi$ Transp., 115th Cong. app. at 51 (2017) (response to written questions submitted by Hon. John Thune, Chairman, S. Comm. on Com., Sci., \& Transp. to Hon. Maureen K. Ohlausen, Acting Chairman, Federal Trade Commission) ("[F]ighting fraud is at the core of the FTC's consumer protection mission.").

18 See John Harrington, Up in Smoke: The FTC's Refusal to Apply the "Unfairness Doctrine" to Camel Cigarette Advertising, 47 FED. COMMC'NS L.J. 593, 594-95 (1995) (detailing the Commission's 3-2 vote to close its investigation of R.J. Reynolds despite substantial evidence that its marketing practices were unfair); see also Dara J. Diomande, The Re-Emergence of the Unfairness Doctrine in Federal Trade Commission and State Consumer Protection Cases, 18 ANTITRUST 53, 55 (2004) (noting that the Commission's revised unfairness standard helped doom its initial investigation of R.J. Reynolds).

19 See Press Release, FTC, Joe Camel Advertising Campaign Violates Federal Law, FTC Says (May 28, 1997), https://www.ftc.gov/news-events/press-releases/1997/05/joe-camel-advertisingcampaign-violates-federal-law-ftc-says [https://perma.cc/U5LF-EZSW] (announcing that the Commission would sue R.J. Reynolds after receiving congressional requests to "reopen a prior investigation of the Joe Camel campaign"); Press Release, FTC, Federal Trade Commission Dismisses Joe Camel Complaint (Jan. 27, 1999), https://www.ftc.gov/news-events/pressreleases/1999/01/federal-trade-commission-dismisses-joe-camel-complaint

[https://perma.cc/NMT6- $\left.{ }_{52} \mathrm{~T}\right]$ (announcing that the Commission's complaint had been mooted by the multistate tobacco settlement).

20 See Financial Services and General Government Appropriations for 2009: Hearing Before the $H$. Comm. on Appropriations Subcomm. on Fin. Servs. E Gen. Gov't, 11oth Cong. 255 n.11 (2008) (statement of Lydia B. Panes, Director of the Bureau of Consumer Protection, Federal Trade Commission) (listing FTC enforcement actions related to mortgage lending). Consistent with this heavy emphasis on fraud, when the FTC did sue the nation's largest subprime lender in 2007, it was to challenge do-not-call violations; Ameriquest's lending practices went unchallenged. Press Release, FTC, FTC Announces Law Enforcement Crackdown on Do Not Call Violators (Nov. 7, 2007), https://www.ftc.gov/newsevents/press-releases/2007/11/ftc-announces-law-enforcement-crackdown-do-not-call-violators [https://perma.cc/6DUJ-AM 59]. In contrast, states acted early to challenge unfair predatory lendingincluding practices by Ameriquest. See, e.g., Press Release, Iowa Dep't of Just., Off. of the Att'y Gen., States Settle with Household Finance up to $\$ 484$ Million for Consumers (Oct. 11, 2002), 
corrected" in the form of a global economic meltdown. The FTC's underenforcement contributed to Congress' stripping the Agency of major authorities over the financial sector, including rulemaking on mortgages, debt collection, and credit reporting. ${ }^{21}$

During that same decade, the Agency largely ignored the explosion in predatory for-profit colleges, which fueled a massive number of student loan defaults. ${ }^{22}$ This inaction led to enormous costs to both consumers and taxpayers. ${ }^{23}$ Similarly, even as fraud and delinquencies rose in the auto market, ${ }^{24}$ the FTC declined to take comprehensive action to protect military

https://www.iowaattorneygeneral.gov/newsroom/states-settle-with-household-finance-up-to-484million-for-consumers [https://perma.cc/ $\mathrm{X}_{2} \mathrm{GE}-5 \mathrm{HEU}$ ] (describing state-led settlement with Household Finance for deceptive lending practices); see also Press Release, Off. of Ill. Att'y Gen., Madigan, Martinez: Ameriquest to Pay \$325 Million and Reform Lending Practices to Resolve States' Investigation (Jan. 26, 2006), https://illinoisattorneygeneral.gov/pressroom/2006_01/20060123b.html [https://perma.cc/DKC9- $\mathrm{C}_{7} \mathrm{~S}_{4}$ ] (reporting about the Illinois settlement against Ameriquest for "unfair and deceptive conduct that amounted to predatory lending and put people at risk of losing their homes").

21 As the mortgage crisis worsened during this era, the FTC's inaction against unfair lending practices was criticized with growing intensity. In 2008, Senator Byron Dorgan accused the FTC of being "absent" on subprime lending, while others, including Senator Bill Nelson, zeroed in on the Agency's failure to challenge unfair lending products. See Improving Consumer Protections in Subprime Lending: Hearing Before the Subcomm. on Interstate Com., Trade, छ Tourism, of the S. Comm. on Com., Sci., \& Transp., 110th Cong. 9, 21 (2008). One year later, at another hearing where the FTC's enforcement track record was challenged, another witness described the Agency as being "completely passive" in using its unfairness authority against subprime lending. See Consumer Credit and Debt: The Role of the Federal Trade Commission in Protecting the Public: Hearing Before the Subcomm. on Com. Trade, E Tourism, of the H. Comm. on Energy \& Com., 111th Cong. 99-100 (2009) (statement of Ira Rheingold, Executive Director, National Association of Consumer Advocates).

Members of Congress also criticized the FTC's unfairness standard, which had been narrowed in the 1980s. For example, in 2007, the Chairman of the House Financial Services Committee, Representative Barney Frank, argued there was "broad consensus" that the Agency's standard was too rigid to tackle emerging unfair lending abuses. See Improving Federal Consumer Protection in Financial Services: Hearing Before the H. Comm. on Fin. Servs., 110th Cong. 40 (2007). At the same hearing, then-Federal Deposit Insurance Corporation Chair Sheila Bair called unfairness a "restrictive legal standard," and argued that Congress should consider enacting a more flexible standard to tackle some of the most problematic practices of the era. Id.

22 See generally Statement of Commissioner Rohit Chopra, FTC, University of Phoenix, FTC File No. 1523231, 2019 WL 6838771 (F.T.C.) (Dec. 10, 2019), https://www.ftc.gov/system/files/ documents/public_statements/1557180/152_3231_statement_of_commissioner_rohit_chopra_0.pdf [https://perma.cc/7ZTV-HD 38 ] (describing the FTC's track record on enforcement actions against for-profit college deception); ADAM LOONEY \& CONSTANTINE YANNELIS, THE BROOKINGS INST., A CRISIS IN STUDENT LOANS? HOW CHANGES IN THE CHARACTERISTICS OF BORROWERS AND IN THE INSTITUTIONS THEY ATTENDED CONTRIBUTED TO Rising LOAN DEFAULTS (2015), https://www.brookings.edu/wp-content/uploads/2015/og/LooneyTextFall15BPEA.pdf [https://perma.cc/SY6T-SGUE].

23 See LOONEY \& YANNELIS, supra note 22.

24 See Ben Eisen \& AnnaMaria Andriotis, An $\$ 809$ Car Payment, a $\$ 660$ Income: How Dealers Make the Math Work, WALL ST. J. (Dec. 21, 2019, 5:30 AM), https://www.wsj.com/articles/an-809-carpayment-a-66o-income-how-dealers-make-the-math-work-11576924201 [https://perma.cc/BKK3-GKHF] (reporting on the growing prevalence of fraud in auto finance). 
families and the general public, in spite of Congress having given the Agency specific authority to do so. 25 These are just a handful of real world examples where government inaction resulted in massive harm for consumers, small businesses, and the economy.

Restoring the FTC as a vigorous check on corporate abuse is long overdue. This means not only reorienting the Agency to focus on the largest problems in the marketplace, but also resurrecting the legal tools that were shelved during the Miller era. ${ }^{26}$ Then-Commissioner Chopra made this a key focus during his tenure.

Director Chopra has not called on the Agency to return to its pre-1980 approach. Rather, he believes the Commission should be monitoring and analyzing emerging business practices by major industry players, while inventorying its existing authorities to identify how it can better correct and deter wrongdoing. For example, he has highlighted the Agency's long unused competition rulemaking powers, ${ }^{27}$ and has pointed to problems stemming from how the Agency has underused its unfairness authority. ${ }^{28} \mathrm{He}$ has called on the Commission to rethink its reliance on case-by-case enforcement, and to issue restatement rules that increase deterrence without imposing any burdens on businesses. ${ }^{29} \mathrm{He}$ has argued that reviving these tools should be a

25 See 12 U.S.C. $§ 5519$ (d) (authorizing the Commission to issue baseline protections for auto consumers and directing the Commission to work with other agencies to combat illegal practices targeting service members). This inaction has come under criticism. See, e.g., GIDEON WEISSMAN, R.J. CROSS, ED MiERZWINSKI \& LUCY BAKER, AUTO LOAN COMPLAINTS RISE 5, 29 (2020), https://uspirg.org/sites/pirg/files/reports/AutoLoanComplaintsRise/WEB_USP_CFPB-Auto-

Loan_Report_1020_v1.pdf [https://perma.cc/M4DG-XRV4] (calling on the Commission to deploy its dormant rulemaking authority to combat growing problems in the auto market).

26 See supra notes 10-14 and accompanying text.

27 See generally Rohit Chopra \& Lina M. Khan, The Case for "Unfair Methods of Competition" Rulemaking, 87 U. CHI. L. REV. 357 (2020) (calling for the use of rulemaking under $\S 5$ of the FTC Act).

28 See Comment Before the Dep't of Transp., supra note 13, at 1-2 (encouraging the Department of Transportation to abandon efforts to adopt the FTC's post-1980 unfairness standard).

29 See Statement of Commissioner Rohit Chopra, FTC, Activating Civil Penalties for Made in USA Fraud, 2019 WL 1766100 (F.T.C.), at ${ }^{*} 1$ (Apr. 17, 2019), https://www.ftc.gov/system/files/ documents/public_statements/1514808/chopra_-_activating_civil_penalties_for_made

_in_usa_fraud_4-17-19.pdf [https://perma.cc/P6JT-MAFS] (calling on the Commission to issue a Made in USA rule); Statement of Commissioner Rohit Chopra, FTC, Regarding the Report to Congress on the FTC's Use of Its Authorities To Protect Consumer Privacy and Security, FTC File No. P065404, 2020 WL 3473532, at * ${ }_{1}$ (June 17, 2020) [hereinafter Statement Regarding the Rep. to Cong. on Privacy and Security], https://www.ftc.gov/system/files/documents/public_statements/ 1577067/p065404dpipchoprastatement.pdf [https://perma.cc/5DAR- $\left.{ }_{5} \mathrm{~S}_{5} \mathrm{~V}\right]$ (calling on the Commission to inventory, publish, and deploy its unused rulemaking powers); Statement of Commissioner Rohit Chopra, FTC, Regarding the Report to Congress on Protecting Older Consumers, FTC File No. P144400 (Oct. 19, 2020), https://www.ftc.gov/system/files/documents/ public_statements/1581862/p14440ochoprastatementolderamericansrpt.pdf [https://perma.cc/2A $\mathrm{A}_{5} \mathrm{G}$ $\mathrm{QZ} 5 \mathrm{~A}]$ (calling on the Commission to initiate a restatement rulemaking). 
key priority of the Commission, regardless of the Commission's equitable authorities under $\S 13(\mathrm{~b})$.

This Article highlights another power that the Commission should resurrect: the Penalty Offense Authority, codified in $\S 5(\mathrm{~m})(1)$ (B) of the FTC Act. ${ }^{30}$ This provision, which authorizes the Commission to seek civil penalties for first-time offenses, can be used to systematically eradicate unfair or deceptive practices through administrative adjudication and market participant notification. It is a unique tool in commercial regulation that has the potential to dramatically increase the Agency's effectiveness. ${ }^{31}$ The Agency can use the authority not only to correct harmful practices, but also to deter them, while providing unusually strong due process for defendants. ${ }^{32}$ Deploying this authority should be part of a broader shift away from one-off enforcement actions and toward systematic efforts to combat widespread harms.

This Article proceeds in four parts. Part I outlines the Commission's authorities to seek monetary remedies, including the challenged authorities under $\S 13$ (b) of the FTC Act. Part II details the drawbacks of the Commission's heavy reliance on seeking equitable monetary relief through $\S 13(\mathrm{~b})$, rather than seeking civil penalties under other authorities. Part III describes the Penalty Offense Authority and details the key advantages that the authority confers. Finally, Part IV offers examples where a penalty offense strategy would be particularly fruitful, including actions the Commission can take almost immediately to significantly step up its deterrence of harmful practices.

\section{Overview of the Federal Trade Commission's Authorities and its Heavy Reliance on $\S 13(\mathrm{~B})$}

Section 5 of the FTC Act prohibits unfair and deceptive practices and unfair methods of competition. ${ }^{33}$ When the Commission has reason to believe that $\S 5$, or other laws it enforces, has been violated, it can sue to halt the violations either in an administrative proceeding or in federal court. 34

When proceeding administratively, the Commission files a complaint, which an administrative law judge (ALJ) adjudicates according to the Commission's current Rules of Practice. ${ }^{35}$ After hearing the evidence, the ALJ issues an Initial Decision setting forth findings of fact and conclusions of law,

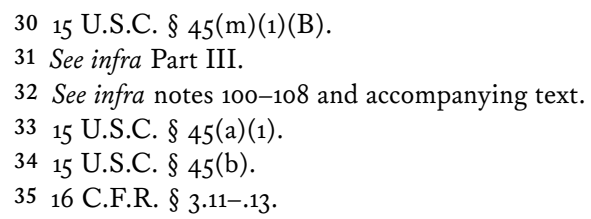


which the full Commission can later review. ${ }^{36}$ The Commission then issues a final decision and order, which can be appealed to a United States Court of Appeals and then to the Supreme Court. ${ }^{37}$

The Commission can also file complaints in a U.S. District Court. 38 When it does so, it essentially assumes the role of any other plaintiff in federal court. Cases are heard by an Article III judge (or in rare cases, a jury), and rulings can be appealed to the Court of Appeals and then to the Supreme Court.

There are various remedies the Commission can seek depending on where it is filing its complaint, and under which authorities it is doing so. In the remainder of this Part, we detail the key remedies available to the Commission, the tools with which it can seek these remedies, and the Commission's overwhelming recent reliance on a single one of these tools$\S 13(\mathrm{~b})$ of the FTC Act.

\section{A. Overview of Remedies Available to the Commission}

There are generally two categories of remedies the Commission can seek in litigation: injunctive relief and monetary relief. ${ }^{39}$ As detailed further below, injunctive relief can be either permanent or preliminary, while monetary relief encompasses both equitable monetary relief and civil penalties. ${ }^{40}$

An injunction is a court order that compels or restrains a party from engaging in a particular act. ${ }^{41}$ For example, the Commission will frequently seek cease-and-desist orders, whereby parties are directed to halt their lawbreaking conduct. ${ }^{42}$ The Commission can also seek "fencing-in" reliefremedies to prevent parties from continuing their lawbreaking, such as requirements that outside monitors be appointed. ${ }^{43}$ When issued following a trial or dispositive motion, injunctions can be permanent. However, the FTC can also seek preliminary injunctions and temporary restraining orders under certain circumstances. 44

3616 C.F.R. $\S 3.51$.

3715 U.S.C. $\S 45(\mathrm{c})$.

3815 U.S.C. $\S 45(\mathrm{~m})(1)(\mathrm{A})$.

39 See Table 1 infra.

$40 \mathrm{Id}$.

41 Injunction, BLACK'S LAW DICTIONARY (11th ed. 2019).

42 A Brief Overview of the Federal Trade Commission's Investigative, Law Enforcement, and Rulemaking Authority, FTC (May 2021), https://www.ftc.gov/about-ftc/what-we-do/enforcementauthority [https://perma.cc/54 $\left.\mathrm{N}_{2}-3 \mathrm{UZX}\right]$.

43 See FTC v. Colgate-Palmolive Co., 380 U.S. 374, 395 (1965) ("Having been caught violating the [FTC] Act, respondents 'must expect some fencing in." (quoting FTC v. Nat'l Lead Co., 352 U.S. 419, 431 (1957))); Telebrands Corp. v. FTC, 457 F.3d 354, 357 n.5 (4th Cir. 2006) (finding the Commission can seek injunctions "that are broader than the conduct that is declared unlawful").

4415 U.S.C. $\S 53(\mathrm{~b})$. 
In addition to injunctive relief, the Commission can seek monetary relief from wrongdoers, which generally takes the form of either equitable relief or civil penalties. Equitable monetary relief is designed to restore the status quo absent the wrongdoing. This has traditionally been accomplished in one of two ways: wrongdoers can be ordered to turn over their illegal earnings-a remedy known as disgorgement-or they can be ordered to compensate consumers for their losses, a remedy known as restitution. 45 These remedies can often be mirror images of one another, but they are conceptually distinct and could yield different outcomes. For example, suppose a corporation charged consumers $\$ 90$ million in inaccurate late fees, which was the result of corner cutting that saved the corporation $\$ 10$ million. Under those circumstances, the company's total unjust gains were $\$ 100$ million, while consumers' losses totaled $\$ 90$ million.

Importantly, regardless of how the remedy is characterized, courts in equity generally award only direct consumer losses or direct illegal earnings or avoided costs. Monetary awards that exceed revenue or losses may be deemed punitive, rather than remedial, and the Supreme Court has indicated that punitive awards are typically unavailable in equity. ${ }^{46}$ Returning to the example above, even if the real harm to consumers exceeded $\$ 90$ millionfor example, if the bank charged them overdraft fees-the most a court can order through restitution is $\$ 90$ million. Similarly, even if the company realized more than $\$ 100$ million in gains-for example, if it plowed these profits into a successful marketing campaign-these additional gains are generally not recoverable.

The Commission can also seek civil penalties. 47 In contrast to equitable remedies, civil penalties are intended to punish the wrongdoer, rather than simply restore the status quo. 48 They are calculated based on maximum penalty amounts laid out by law, typically on a per-violation basis, rather than victims' losses or wrongdoers' gains. ${ }^{49}$ For example, under certain statutes the FTC enforces, defendants can be liable for up to $\$ 43,280$ per violation, 50 which can add up quickly for established corporate actors operating across the country.

45 See FTC v. Stefanchik, 559 F.3d 924, 931 (9th Cir. 2009) (defining restitution as the "full amount lost by consumers," regardless of profits); FTC v. Bronson Partners, LLC, 654 F.3d 359, 372 (2d Cir. 2011) (defining disgorgement as "a method of forcing a defendant to give up the amount by which he was unjustly enriched" (quoting SEC v. Commonwealth Chem. Sec., Inc., 574 F.2d 90, 102 (2d Cir. 1978))).

46 See Liu v. SEC, 140 S. Ct. 1936, 1942 (2020) (explaining that relief that exceeds profits was not "typically available in equity").

47 See, e.g., 15 U.S.C. $\S 45(\mathrm{~m})(1)(\mathrm{C})$.

48 Kokesh v. SEC, 137 S. Ct. 1635,1642 (2017).

$49 \mathrm{Id}$.

50 See Press Release, FTC, FTC Publishes Inflation-Adjusted Civil Penalty Amounts (Jan. 13, 2020), https://www.ftc.gov/news-events/press-releases/2020/01/ftc-publishes-inflation-adjusted-civil- 
Notably, to seek civil penalties under the FTC Act, the Commission must typically refer complaints to the Attorney General, who can file a complaint on behalf of the United States or return it to the Commission to pursue independently.51 For ease of reference throughout this Article, it will be assumed the Commission is litigating in its own name, though we discuss the referral process further below.

\section{B. Overview of FTC Tools}

The remedies available to the Commission depend on the authorities the Agency invokes. In this Section, each of the Commission's primary authorities will be discussed in turn, concluding with a discussion of the FTC's heavy reliance on $\S 13(\mathrm{~b})$.

Under $\S 5(\mathrm{~b})$ of the FTC Act, the Commission can initiate an administrative proceeding to halt unfair or deceptive practices, unfair methods of competition, or violations of other laws enforced through the FTC Act. ${ }^{52}$ Generally, only injunctive relief is available through $\S 5(\mathrm{~b})$, and only through a final order. Preliminary injunctions are not available, and monetary relief cannot be awarded under current practice, except in a settlement. ${ }^{53}$

When the Commission's administrative (as opposed to federal court) orders have been violated, $\S 5(l)$ of the FTC Act authorizes the Commission to seek injunctive relief, equitable monetary relief, and civil penalties in federal court. ${ }^{54}$

Section $5(\mathrm{~m})$ of the FTC Act also allows the Commission to seek civil penalties in federal court. Section $5(\mathrm{~m})(1)(\mathrm{A})$ allows the Commission to seek civil penalties if a party has violated a Commission rule, ${ }^{55}$ while $\S 5(\mathrm{~m})(1)(\mathrm{B})$ allows the Commission to seek penalties against a party that engages in conduct it knows has been determined to be unlawful in a Commission

penalty-amounts [https://perma.cc/U6GM-XXYW] (announcing that the maximum civil penalty under a number of FTC authorities had risen to $\$ 43,280$ ).

5115 U.S.C. $\$ 56$.

5215 U.S.C. $\S 45(\mathrm{~b})$.

53 See Heater v. FTC, 503 F.2d 321, 321-22 (9th Cir. 1974) (finding that the Commission could not order redress in an administrative proceeding). However, the Commission can use other authorities in tandem with $\S 5(\mathrm{~b})$ to seek both preliminary and monetary relief in connection with administrative litigation. See generally, A Brief Overview of the Federal Trade Commission's Investigative, Law Enforcement, and Rulemaking Authority, FTC (May 2021), https:/www.ftc.gov/about-ftc/what-we-do/enforcementauthority [https://perma.cc/K2WH-KL6S]

54 See 15 U.S.C. $\S 45(l)$.

5515 U.S.C. $\S 45(\mathrm{~m})(1)(A)$ authorizes penalties against persons, partnerships, or corporations who engage in unfair or deceptive acts or practices "with actual knowledge or knowledge fairly implied on the basis of objective circumstances that such act is unfair or deceptive and is prohibited by such rule." 15 U.S.C. $\S 45(\mathrm{~m})(1)(\mathrm{A})$. 
order. ${ }^{56}$ That latter authority, the Penalty Offense Authority, is the primary focus of this Article.

Another key tool for the Commission is $\S 19$ of the FTC Act. ${ }^{77}$ This section of the FTC Act authorizes federal courts to order redress, notice, other equitable relief, and damages. ${ }^{58}$ Section 19 can be invoked in two circumstances. First, if the conduct violated a trade regulation rule, the Commission can proceed directly to federal court to seek $\S 19$ remedies. ${ }^{59}$ Second, if a reasonable person would consider the conduct at issue to be dishonest or fraudulent, the Commission can seek relief through a two-step process. The FTC must first conduct an administrative proceeding that leads to a final order, and it can then proceed to federal court to seek further relief.60

Finally, for decades, $\S 13$ (b) of the FTC Act was seen as authorizing the Commission to go directly to federal court to seek a wide range of remedies, including preliminary and permanent injunctions, restitution, and disgorgement. ${ }^{61} \mathrm{~A}$ key advantage of this interpretation of $\S 13(\mathrm{~b})$ was that it could be used to enforce "any provision of law enforced by the Federal Trade Commission." 62 The flexibility this authority afforded the Commission was a

56 The final Commission order cannot be a consent order. Id. $\S 45(\mathrm{~m})(1)(\mathrm{B})$. Although $\S 5(\mathrm{~m})$ does not explicitly authorize seeking equitable relief in such cases, $\S 16$ of the FTC Act authorizes the Commission to refer actions for equitable relief-in particular, actions under $\S 13$ (b) and $\S 19-$ to the Attorney General. 15 U.S.C. $\S 56(\mathrm{a})(1)$. This means that if violators of a rule (in the case of $5(\mathrm{~m})(\mathrm{1})(\mathrm{A})$ actions) or of a Commission finding (in the case of $5(\mathrm{~m})(\mathrm{1})(\mathrm{B})$ actions) have also violated the FTC Act, the Attorney General can, upon the FTC's referral, seek equitable relief (including monetary relief) in addition to civil penalties. See, e.g., Press Release, FTC, Debt Management Telemarketers Settle FTC Charges (June 15, 2006), https://www.ftc.gov/news-events/pressreleases/2006/o6/debt-management-telemarketers-settle-ftc-charges [https:/perma.cc/RQ5 C-YAK6] (describing both the civil penalties and redress in an action filed by the United States).

5715 U.S.C. $\S 57 \mathrm{~b}(\mathrm{~b})$.

58 Id.; Black's Law Dictionary defines consequential damages as "[1]osses that do not flow directly and immediately from an injurious act, but that result indirectly from the act." Damages, BLACK'S LAW DICTIONARY (11th ed. 2019). We have been unable to identify a $\S 19$ matter where the FTC pursued damages, which is traditionally understood to be a legal remedy rather than an equitable remedy. Unlike equitable relief, damages can conceivably capture a broad range of harms, including indirect consequences of deception. As the FTC faces threats to its authority to seek equitable relief, the Agency should consider pursuing this alternative form of relief in more cases.

59 See 15 U.S.C. $\S 57 \mathrm{~b}(\mathrm{a})(1)$ ("[T]he Commission may commence a civil action against such person, partnership, or corporation for relief under subsection (b) in a United States district court or in any court of competent jurisdiction of a State.").

60 See 15 U.S.C. $\S 57 \mathrm{~b}(\mathrm{a})(2)$.

61 Specifically, the second proviso of $\S 13(\mathrm{~b})$ authorizes the FTC to seek, and district courts to grant "a permanent injunction" without the FTC's initiating administrative proceedings. See FTC v. H.N. Singer, Inc., 668 F.2d 1107, 1110 (9th Cir. 1982); FTC v. U.S. Oil \& Gas Corp., 748 F.2d 1431, 1434-35 (11th Cir. 1984). Once their equitable authority is invoked, district courts may employ their inherent powers to grant preliminary equitable relief (such as asset freezes) and permanent relief, including equitable monetary relief. U.S. Oil \& Gas, 748 F.2d at 1434-35; FTC v. Gem Merch. Corp., 87 F.3d 466, 468-69 (11th Cir. 1996) (holding that a full range of equitable remedies are available).

6215 U.S.C. $\S 53(\mathrm{~b})$. 
key reason the Agency came to rely on it overwhelmingly when seeking relief in federal court. However, as discussed in the next Section, the Agency's powers under this provision were recently vitiated by the Supreme Court.

Table 1: Overview of Federal Trade Commission Act Authorities to Seek Monetary Relief ${ }^{63}$

\begin{tabular}{|c|c|c|}
\hline Authority & Description & $\begin{array}{l}\text { Remedies } \\
\text { Available }\end{array}$ \\
\hline $13(\mathrm{~b})$ & $\begin{array}{l}\text { For violations of any law enforced } \\
\text { by the Commission, the } \\
\text { Commission may, on its own } \\
\text { accord, seek injunctions and other } \\
\text { equitable relief in federal court }\end{array}$ & $\begin{array}{l}\text { Until } A M G \text {, } \\
\text { Restitution, } \\
\text { Disgorgement } \\
\text { of Ill-Gotten } \\
\text { Gains, Other } \\
\text { Equitable } \\
\text { Relief }\end{array}$ \\
\hline $\begin{array}{l}\text { 19(a)(1), } \\
19(b)\end{array}$ & $\begin{array}{l}\text { For violations of any rule defining } \\
\text { an unfair or deceptive act or } \\
\text { practice, the Commission may, on } \\
\text { its own accord, commence a civil } \\
\text { action in federal court }\end{array}$ & \multirow[b]{2}{*}{$\begin{array}{l}\text { Restitution, } \\
\text { Other } \\
\text { Equitable } \\
\text { Relief, } \\
\text { Damages }\end{array}$} \\
\hline $\begin{array}{l}\text { 19(a)(2), } \\
19(\mathrm{~b})\end{array}$ & $\begin{array}{l}\text { For violations of the Act's } \\
\text { prohibition on unfair or deceptive } \\
\text { acts or practices, the Commission } \\
\text { can enter a final cease and desist } \\
\text { order condemning the act or } \\
\text { practice in question. After the } \\
\text { Commission enters the final order, } \\
\text { the Commission may, on its own } \\
\text { accord, commence a civil action in } \\
\text { federal court, so long as the } \\
\text { conduct would have been } \\
\text { reasonably known to be "dishonest } \\
\text { or fraudulent" }\end{array}$ & \\
\hline $5(I)$ & $\begin{array}{l}\text { For violations of any final cease and } \\
\text { desist order entered by the } \\
\text { Commission, the Commission may }\end{array}$ & $\begin{array}{l}\text { Civil Penalties, } \\
\text { Restitution, } \\
\text { Disgorgement, }\end{array}$ \\
\hline
\end{tabular}

63 This excludes authorities specifically authorized by other statutes subject to FTC enforcement. Some statutes enumerate conduct that should be treated as rule violations under the FTC Act. See, e.g., 15 U.S.C. $\S 45(c) ; 15$ U.S.C. $\S 6502(c) ; 15$ U.S.C. $\S 45$ b(d)(1). 


\begin{tabular}{lll}
\hline \hline & $\begin{array}{l}\text { refer a complaint for civil penalties } \\
\text { and other relief to the Attorney } \\
\text { General }\end{array}$ & $\begin{array}{l}\text { Other } \\
\text { Equitable } \\
\text { Relief }\end{array}$ \\
\hline $5(\mathrm{~m})(\mathbf{1})(\mathrm{A})$ & $\begin{array}{l}\text { For knowing violations of any trade } \\
\text { regulation rule, the Commission } \\
\text { may refer a complaint for civil } \\
\text { penalties to the Attorney General }\end{array}$ \\
\hline $5(\mathrm{~m})(\mathbf{1})(\mathrm{B})$ & $\begin{array}{l}\text { For non-parties that knowingly } \\
\text { violate litigated final orders, the }\end{array}$ \\
& $\begin{array}{l}\text { Commission may refer a complaint } \\
\text { for civil penalties to the Attorney } \\
\text { General }\end{array}$ \\
\hline
\end{tabular}

\section{The Commission's Reliance on $\S 13(b)$}

While the Commission retains a number of avenues to pursue monetary relief, since the 1980 s the Agency has relied overwhelmingly on $\S 13(\mathrm{~b}) .64$ As noted above, $\S 13$ (b) offered certain advantages over other enforcement routes. Whenever the Commission had reason to believe a party is violating or is about to violate the law, the Commission could go to federal court independently to seek both preliminary relief-including temporary restraining orders, asset freezes, and the appointment of receivers-and permanent relief, including injunctions and orders of disgorgement and restitution.

When the Commission has not used $\S 13(\mathrm{~b})$, it generally relies on $\S 5(\mathrm{~b})-$ the Commission's authority to seek and to issue administrative cease-anddesist orders. 65

Annual statistics compiled by the Commission reveal the Agency's heavily historic reliance on $\S 13(\mathrm{~b})$ and administrative lawsuits. In 2018, according to our analysis, nearly eighty-eight percent of the Commission's consumer protection lawsuits were brought either through $\S 13(\mathrm{~b})$ or the Commission's administrative forum, and the Commission did not obtain monetary relief in

64 See infra notes 66-67 and accompanying text.

6515 U.S.C. $\S 45(\mathrm{~b})$. 
any of the administrative actions. 66 This has been a consistent pattern in recent history, spanning multiple Commissions. ${ }^{67}$

While the Commission came to rely overwhelmingly on $\S 13(\mathrm{~b})$, that reliance now leaves the Agency exposed. In April, the Supreme Court held unanimously that $\S 13(\mathrm{~b})$ does not authorize the Commission to seek equitable monetary relief in federal court, overruling decades of circuit precedent. 68 In addition, in 2019, the Third Circuit held that the Commission must show defendants are violating or about to violate the law in order to invoke $\S 13(\mathrm{~b}) .69$ This means that for misconduct that has ceased, the Commission may be unable even to seek an injunction through $\S 13(\mathrm{~b})$.

Section 13(b) has been a vital tool for the Commission, and the Supreme Court's decision is a major loss. However, even before this decision was issued, the Commission's overreliance on $\S 13(\mathrm{~b})$ carried serious drawbacks.

\section{Drawbacks of Overreliance on $\S 13(\mathrm{~b})$}

While the Commission's ability to seek monetary relief through $\S 13(\mathrm{~b})$ has now been stripped, the problems with the Commission's historic reliance on this authority go well beyond adverse decisions by certain federal courts. As Congress considers restoring the Commission's equitable authorities under $\S 13(\mathrm{~b})$, it is important to recognize the drawbacks of relying on these authorities alone.

In particular, because $\S 13(\mathrm{~b})$ allowed the Commission to seek restitution and disgorgement rather than penalties or damages, it proved to be an imperfect tool, particularly in two types of circumstances. The first is where

66 To conduct this analysis, the number of federal actions-where $\S 13(\mathrm{~b})$ is invoked-plus the number of administrative actions were divided by the total number of actions. See Stats $\mathcal{E}$ Data 2018 , FTC, https://www.ftc.gov/reports/annual-highlights-2018/stats-and-data [https://perma.cc/3W4 4 HFGFH] (noting that the Commission filed 40 federal court actions, 18 administrative actions, and 8 actions to seek civil penalties). For other annual reports, see FTC Annual Reports, FTC, https:// www.ftc.gov/policy/reports/policy-reports/ftc-annual-reports [https://perma.cc/8AGL-WPQV].

67 According to our analysis, over the last five years, nearly ninety percent of the Agency's actions were brought under $\S 13$ (b) or $\S 5$ (b). See Stats \& Data 2019, FTC, https://www.ftc.gov/reports/annualhighlights-2019/stats-and-data [https://perma.cc/3G72-ENRL]; Stats \& Data 2018, FTC, https://www.ftc.gov/reports/annual-highlights-2018/stats-and-data [https://perma.cc/3W4H-FGFH]; Stats $\mathcal{E}$ Data 2017, FTC, https:/www.ftc.gov/reports/annual-highlights-2017/stats-and-data [https:// perma.cc/8P 2 H-SDPK]; Stats \& Data 2016, FTC, https://www.ftc.gov/node/1205233 [https:// perma.cc/V3BU-UJQS]; Stats E Data 2015, FTC, https://www.ftc.gov/node/943403 [https://perma.cc/ DQY7-JPJ5]. This trend appears to have begun in the 1980s, when the Commission launched its ${ }_{13}(\mathrm{~b})$ program targeting fraud. Kirkpatrick, supra note 3, at 77-78 (1989) (noting that $\S 13(\mathrm{~b})$ had become the "foundation of the Commission's consumer fraud program").

68 AMG v. FTC, 141 S. Ct. 1341, 1344 (2021).

69 See, e.g., FTC v. Shire ViroPharma, Inc., 917 F.3d 147, 150, 161 (3d Cir. 2019) (holding that under $\S 13(\mathrm{~b})$, the FTC must show defendants are about to violate the law). 
the degree of harm or ill-gotten revenue is subject to dispute. The second is where misconduct is so harmful and distortionary to consumers and competitors that equitable relief is unlikely to deter other wrongdoers or provide adequate relief to victims. Under those circumstances, described further below, $\S 13$ (b) has proven to be a poor fit for correcting and deterring widespread harms.

\section{A. Hard-to-Quantify Harm}

Section 13(b) of the FTC Act does not expressly address monetary relief, nor does it offer guidance on how such relief should be quantified. Rather, it authorizes the Commission to seek permanent injunctions, which until $A M G$, was seen as also allowing courts to award ancillary relief such as restitution and disgorgement. How these remedies are calculated has been shaped by decades of precedent.

Many of the Commission's earliest cases brought under $\S 13(\mathrm{~b})$ involved defendants engaged in routine frauds-often, the equivalent to criminal theft-so in the years before $A M G$, those cases have shaped how courts calculate and award monetary relief in cases brought through 13 (b)..$^{70}$

As a general matter, early case law held that to seek monetary relief under $\S 13(\mathrm{~b})$, it was the Commission's initial burden to approximate harm or unjust gains. ${ }^{71}$ However, district courts could use gross receipts (i.e., the total revenue earned in connection with the wrongful practices) as a starting point in most circumstances, while allowing defendants to submit evidence that

70 See generally J. Howard Beales III \& Timothy J. Muris, Striking the Proper Balance: Redress Under Section 13(B) of the FTC Act, 79 ANTITRUST L.J. 1 (2013) [hereinafter Beales \& Muris] (describing the early origins of the Commission's $13(\mathrm{~b})$ fraud program).

$71 \mathrm{Id}$. at $22-28$. 
would reduce that award. ${ }^{72}$ Generally speaking, the value of a product received was not subtracted from consumer redress. ${ }^{73}$

This can be an effective formula for seeking monetary relief in cases involving conduct that amounts to criminal theft, where consumers receive nothing of value. However, the Commission encountered difficulty in cases involving companies that sell products or services that have some use or value. ${ }^{74}$ Although the early 13 (b) case law suggested that seeking full redress may be appropriate even in cases involving products of value, well-resourced companies can mount aggressive challenges to the Commission's approximation. For example, a common tactic was to retain high-priced

72 Gross receipts can be a starting point for restitution or disgorgement orders once the Commission establishes a presumption of reliance. The Commission need not prove consumer reliance in order to obtain monetary relief for consumers. Rather, it is "entitled to a presumption of consumer reliance" by showing that "(1) the defendant made material misrepresentations or omissions that 'were of a kind usually relied upon by reasonable prudent persons;' (2) the misrepresentations or omissions were widely disseminated; and (3) consumers actually purchased the defendants' products." FTC v. BlueHippo Funding, LLC, 762 F.3d 238, 244 (2d Cir. 2014); see also FTC v. Kuykendall, 371 F.3d 745, 765-66 (10th Cir. 2004) ("When, however, the FTC has shown through clear and convincing evidence that defendants were engaged in a pattern or practice of contemptuous conduct, the district court may use the defendants' gross receipts as a starting point for assessing sanctions."); FTC v. Figgie Int'l, Inc., 994 F.2d 595, 605-06 (9th Cir. 1993) (“A presumption of actual reliance arises once the Commission has proved that the defendant made material misrepresentations, that they were widely disseminated, and that consumers purchased the defendant's product."); FTC v. Sec. Rare Coin \& Bullion Corp., 931 F.2d 1312, 1316 (8th Cir. 1991) ("To satisfy the reliance requirement ... the FTC need merely show that the misrepresentations or omissions were of a kind usually relied upon by reasonable and prudent persons, that they were widely disseminated, and that the injured consumers actually purchased the defendant's products."). Once a presumption of reliance has been established, the Commission has the burden of making a reasonable approximation of monetary relief. FTC v. Bronson Partners, 654 F.3d 359, 368 (2d Cir. 2011) ("[A] two-step burden-shifting framework for calculating monetary relief under section 13 (b)... . requires the FTC to first 'show that its calculations reasonably approximated the amount of the defendant [s'] unjust gains,' after which the burden shifts 'to the defendants to show that those figures were inaccurate." (citation omitted)). Under those circumstances, the starting point for calculating relief is generally total revenue. Figgie Int'l, Inc., 994 F.2d at 606 (holding that the proper amount of monetary relief is total revenue); Kuykendall, $371 \mathrm{~F} .3 \mathrm{~d}$ at 764 (when awarding redress, "the district court may use the defendants' gross receipts as a starting point").

73 See Kuykendall, 371 F.3d at 766 (rejecting efforts to offset gross receipts by the value of the products deceptively sold); FTC v. Bronson Partners, LLC, 674 F. Supp. 2d 373, 386 (D. Conn. 2009) (rejecting efforts to offset any "intrinsic value" consumers received from a deceptively sold weight loss product), aff'd, 654 F.3d 359 (2d Cir. 2011).

74 See Statement of Chairman Joseph J. Simons and Commissioners Noah Joshua Phillips and Christine S. Wilson, Sunday Riley Modern Skincare, LLC, FTC File No. 192-3008, 2020 WL 6589813 (F.T.C.), at *1 (Oct. 21, 2019) [hereinafter Simons Statement], https://www.ftc.gov/system/ files/documents/cases/2020.11.6_sunday_riley_majority_statement_final.pdf [https://perma.cc/D9F $\mathrm{VR}_{2} \mathrm{~K}$ ] ("In some cases, such as frauds where the consumer receives no value, this calculation [of illgotten gains] may be obvious. In others, including Sunday Riley, a legally defensible calculation of ill-gotten gains may be difficult. In such cases, the expenditure of resources needed to develop an adequate evidentiary basis reasonably to approximate ill-gotten gains may substantially outweigh any benefits to consumers and the market."). 
experts to conduct "independent" surveys that show little consumer harm..$^{75}$ This forces the Commission to substantiate its estimate with its own expert analysis, and it can expose the Commission to substantial costs and risks. ${ }^{76}$ Battles over approximating harm are likely to continue even if Congress restores the Commission's $\S 13$ (b) authority.

Because of the difficulty of approximating harm, the Commission has historically been reluctant to seek monetary relief in cases where the Agency anticipates the wrongdoing firm(s) would challenge the government's approximation of harm. ${ }^{77}$ On some occasions, the Commission has proceeded anyway-bringing 13 (b) actions against well-heeled firms even when the outcome is uncertain. ${ }^{78}$ This has sent a strong message that no firm is above the law.

But in a number of areas where harm was seen as difficult to quantify, the Commission has instead resorted to no-money settlements. These settlements systematically undervalue harm and underdeter wrongdoing, but the Commission often views them as preferable to a $13(\mathrm{~b})$ action, which can open the door to costly disputes over approximation of harm.

For example, in cases involving false labeling of otherwise functional products, the Commission - until very recently-has typically turned to nomoney settlements where the wrongdoer pays nothing. ${ }^{79}$ This is also a frequent problem in the FTC's privacy and data security programs, where the vast majority of cases against first-time offenders impose no monetary judgment whatsoever. This is true even in cases of unambiguous harm, such as where valuable data has been stolen, or distortions to the market, such as when enterprises secure contracts by misrepresenting their data security or privacy practices. 80 Finally, underdeterrence is a growing problem in the

75 See, e.g., Petition for Writ of Certiorari, Pom Wonderful v. FTC, 136 S. Ct. 1839, app. at 124 (2016) (No. 15-525); ECM Bio Films, Inc., No: 9358, 2014 WL 5298214 (F.T.C.), at *24-25, ${ }^{*} 40-43$ (Sept. 30, 2014) (Complaint Counsel's Proposed Findings of Facts and Conclusions of Law).

76 See Beales \& Muris, supra note 70, at 40 (analyzing the risks to the 13 (b) program in nonfraud cases).

77 See, e.g., Simons Statement, supra note 74.

78 See, e.g., Press Release, FTC, FTC Alleges Fuel Card Marketer FleetCor Charged Hundreds of Millions in Hidden Fees (Dec. 20, 2019), https://www.ftc.gov/news-events/press-releases/2019/ 12/ftc-alleges-fuel-card-marketer-fleetcor-charged-hundreds-millions [https://perma.cc/78GE-E78G] (challenging alleged violations by a major fuel card marketer and its CEO).

79 See, e.g., Sandpiper of Cal., Inc., No. C-4675, 2019 WL 1786666 (F.T.C.) (Apr. 16, 2019) (reaching a no-money settlement against a seller of military-themed backpacks falsely branded Made in USA); Moonlight Slumber, LLC, No. C-4634, 2017 WL 6507202 (F.T.C.) (Dec. 11, 2017) (reaching a no-money settlement against a seller of mattresses falsely marketed as organic).

80 See, e.g., NTT Global Data Centers Americas, Inc., No. 9386, 2020 WL 3819197 (F.T.C.) (June 30, 2020) (settling with NTT Global Data Centers for $\$ 0$ in spite of evidence that the company obtained contracts based on false privacy promises); Facebook, Inc., No. C-4365, 2012 FTC LEXIS 135 (July 27, 2012) (settling with Facebook for \$o following alleged privacy violations); Google Inc., 
Agency's approach to combatting ills in e-commerce, where the Commission has sought no-money settlements even in cases of egregious fake review fraud, which deeply distorts markets and enables other harms. ${ }^{81}$

No-money settlements against established corporate actors seriously impair the Commission's credibility. The Agency's most important, market moving cases involve established corporate actors, not fly-by-night scammers. Obtaining monetary relief in these cases is critical to not only making victims whole but also changing incentives around breaking the law. ${ }^{82}$ Practices like generating fake reviews or mislabeling products "Made in USA" can be highly profitable, and settlements that allow wrongdoers to retain these profits do almost nothing to deter other firms from engaging in the same misconduct. 83 Indeed, as discussed further in the next Section, congressional frustration with "slap on the wrist" settlements that simply order a wrongdoer to stop breaking the law is a key reason why the Commission was given additional authority to seek monetary relief in these cases. ${ }^{84}$

To be clear, before $A M G$, the Commission was able to deploy $\S 13(\mathrm{~b})$ to obtain robust monetary relief even in cases where the harm or gain was difficult to quantify, and even where the defendant was an established

No. C-4336, 2011 FTC LEXIS 251 (Oct. 13, 2011) (settling with Google for \$o following alleged privacy violations).

81 See Statement of Commissioner Rohit Chopra Joined by Commissioner Rebecca Kelly Slaughter, Sunday Riley, FTC File No. 1923008, 2019 WL 5455466 (F.T.C.), at *2 (Oct. 21, 2019) [hereinafter Sunday Riley Statement], https:/www.ftc.gov/system/files/documents/public_statements/ 1550127/192_3008_final_rc_statement_on_sunday_riley.pdf [https://perma.cc/D9VB-7VVZ] (arguing that a no-money order is unlikely to deter other actors from using fake reviews to boost sales and cheat competitors).

82 For example, the FTC recently recovered $\$ 40$ million from a major payment processor accused of facilitating fraud that cost victims millions. See Press Release, FTC, Worldwide Payment Processor and Payments Industry Executive to Pay \$40.2 Million to Settle FTC Charges of Assisting Fraudulent Schemes and Credit Card Laundering (May 19, 2020), https:/www.ftc.gov/newsevents/press-releases/2020/05/worldwide-payment-processor-payments-industry-executive-pay402 [https://perma.cc/6LRP-GXRS] (announcing a $\$ 40.2$ million settlement from First Data Merchant Services, LLC). This recovery will help make those victims whole, while sending the whole industry a message that facilitating fraud is illegal and costly. See Ellen T. Berge, Leonard L. Gordon \& Katelyn J. Patton, Latest FTC Payment Processing Case Results in \$40 Million Proposed Judgment and ISO Oversight Requirements, AlL ABOUT ADVERTISING L. (May 20, 2020), https://www.allaboutadvertisinglaw.com/2020/05/latest-ftc-payment-processing-case-results-in-40million-proposed-judgment-and-iso-oversight-requirements.html [https://perma.cc/2 $\mathrm{X}_{3} \mathrm{~L}-\mathrm{YBT}$ ] (warning other payment processors to examine the settlement carefully).

83 Professor David Vladeck, who led the FTC's Bureau of Consumer Protection from 2009 to 2012, has explained the importance of seeking redress in deception cases, arguing that "giving companies - 'reputable' or not-one free pass at deceptive advertising is fundamentally at odds with the Commission's consumer protection mandate ...." David C. Vladeck, Charting the Course: The Federal Trade Commission's Second Hundred Years, 83 GEO. WASH. L. REV. 2101, 2116-17 (2015).

84 No-money orders can be appropriate in cases involving novel forms of misconduct, but none of the misconduct described here is novel. See infra Part IV. 
corporate actor. ${ }^{85} \mathrm{But}$, because this often involved a substantial investment of resources, especially against a well-financed actor, the Agency has often turned to no-money administrative settlements-a problem likely to persist even if the Commission's $\S 13$ (b) powers are restored. As discussed further in the next Section, this approach ignores other tools in the Commission's toolbox.

\section{B. Harm that Exceeds Direct Gains or Losses}

The Commission's overreliance on $\S 13(\mathrm{~b})$ has also been problematic when the misconduct at issue cannot be meaningfully remedied through equitable relief. As discussed in the preceding Section, if a swindler steals $\$ 1$ million, the most the Commission generally could compel the swindler to pay under $\S 13(\mathrm{~b})$ is $\$ 1$ million. This limitation undermines deterrence and sells victims short. For would-be swindlers, even before $A M G$, the worst consequence they could face if caught is being forced to return their earnings-hardly a strong deterrent.86 And for victims, the collateral consequences of deceit-such as additional medical care required when a treatment does not work as promised-cannot be recovered at all.

This logic applies not only to small-time scams but also to corporate crime. Certain forms of lawbreaking are either so profitable for wrongdoers or so harmful to victims that equitable monetary relief, especially when it is not paired with sufficient injunctive relief, is grossly insufficient to correct the market distortion and deter other lawbreaking. This occurs frequently in opportunity schemes, where the losses or gains cannot be measured simply by how much the victims are paying the perpetrators.

Opportunity schemes involve the sale of money-making opportunities, as opposed to products or services. For example, in certain multilevel marketing (MLM) programs, would-be participants are promised large incomes if they

85 For example, in a recent settlement with Williams Sonoma, which was accused of disseminating false Made in USA claims, the FTC was able-using its equitable authority-to secure \$1 million for affected consumers. See Press Release, FTC, FTC Approves Final Order Settling Charges that Williams-Sonoma, Inc. Made Overly Broad and Misleading 'Made in USA' Claims About Houseware and Furniture Products (July 16, 2020), https://www.ftc.gov/newsevents/press-releases/2020/o7/ftc-approves-final-order-settling-charges-williams-sonoma-inc [https://perma.cc/Z4CE-CPL9]. This settlement resolved allegations first exposed publicly by TINA.org. See Press Release, Truth In Advertising.org, Williams-Sonoma to Pay \$1 Million to Settle Deceptive Ad Lawsuit Sparked by TINA.org (Apr. 1, 2020), https://www.truthinadvertising.org/ williams-sonoma-to-pay-one-million-to-settle-deceptive-ad-lawsuit-sparked-by-tina-org [https://perma.cc/SN7M-HU8R].

86 See generally Alex Raskolnikov, Deterrence Theory: Key Findings and Challenges, in THE CAMBRIDGE HANDBOOK OF COMPLiANCE 179-92 (Benjamin van Rooij \& D. Daniel Sokol, eds. 2021). For an early discussion of deterrence, see Gary S. Becker, Crime and Punishment: An Economic Approach, 76 J. POL. ECON. 169 (1968). 
enlist as salespeople. If these promises prove hollow, their losses can go far beyond what they paid into the scheme, especially if they pursued the opportunity full time, or took out loans to finance product purchases. ${ }^{87}$

Franchises and gig economy networks can engage in similar forms of deceit, tricking would-be franchisees or gig workers with deceptive earnings claims that can lure them into programs that sap their savings, harm their credit, and deprive them of better opportunities. ${ }^{88}$ This same dynamic can occur in for-profit colleges, where unscrupulous schools will promise a major earnings boost to lure students, only to leave these students with crushing debt, wrecked credit, and lost time. ${ }^{89}$

In cases like these, $\S 13(\mathrm{~b})$ proved to be an inadequate tool, even when the FTC used it effectively..$^{90}$ First, the Commission faced the problem already discussed-any estimate of harm in these matters can be challenged, especially in cases, such as those involving the gig economy, where the victims did not actually pay the wrongdoers. ${ }^{91}$ But these cases involved the additional problem that even one hundred percent disgorgement was likely insufficient. Disgorgement and restitution, unlike legal damages, cover only direct losses or gains - not the collateral consequences of deceit. These consequences, both

87 See Consumer Information: Multi-Level Marketing Businesses and Pyramid Schemes, FTC (May 2021), https://www.consumer.ftc.gov/articles/o065-multi-level-marketing-businesses-and-pyramidschemes [https://perma.cc/9TYK-BKYB] (noting that in illegal pyramid schemes, participants typically "lose everything they invest" and may end up "deeply in debt").

88 For example, in recent years Quiznos' franchisees have accused the brand of a host of abuses, particularly after revenue in the system began to plummet. See Jonathan Maze, A Brief History of Quiznos' Collapse, RESTAURANT BUS. (June 13, 2018), https://www.restaurantbusinessonline.com/ financing/brief-history-quiznos-collapse [https://perma.cc/24NE-EJHN] (describing the business practices that limited franchisees' profits).

89 See, e.g., Jessica Glenza, The Rise and Fall of Corinthian Colleges and the Wake of Debt It Left Behind, THE GUARDIAN (July 28, 2014, 3:57 PM), https://www.theguardian.com/education/2014/ jul/28/corinthian-colleges-for-profit-education-debt-investigation [https://perma.cc/ZPC9-6TBK] (noting that students could be left in debt with credits that are unlikely to transfer); Danielle Douglass-Gabriel, Feds Found Widespread Fraud at Corinthian Colleges. Why are Students Still Paying the Price?, WASH. POST. (Sept. 29, 2016), https://www.washingtonpost.com/news/grade-point/wp/ 2016/09/29/feds-found-widespread-fraud-at-corinthian-colleges-why-are-students-still-paying-theprice [https://perma.cc/7 $\left.\mathrm{YJ}_{5}-5 \mathrm{JKB}\right]$ (noting that nearly 80,000 Corinthian College students are facing debt collection).

90 See, e.g., Statement of Commissioner Rohit Chopra Regarding the Deception of Delivery Drivers by Amazon.com, FTC File No. 1923123, 2021 WL 489843 (F.T.C.), at *2, https:// www.ftc.gov/system/files/documents/public_statements/1587003/20200102_final_rchopra_ statement_v2.pdf [https://perma.cc/5ATD-EEXU] ("[P]reying on workers justifies punitive measures far beyond the restitution provided here, and I believe the FTC should act now to deploy dormant authorities to trigger civil penalties and other relief in cases like this one.").

91 For example, the FTC's 2017 charges against Uber regarding false earnings claims to drivers generated controversy over the appropriate estimation of ill-gotten gains. See Dissenting Statement of Commissioner Maureen K. Ohlhausen, Uber, Inc., FTC File No. 1523082, 2017 WL 395526 (F.T.C.), at ${ }^{*} 1-2$ (Jan. 19, 2017), https://www.ftc.gov/system/files/documents/public_statements/ 1054973/uber_statement_of_commissioner_ohlhausen.pdf [https://perma.cc/2RPH-NLAH]. 
for the victim and perpetrator, can far exceed what the Commission can recover, even if its equitable authority is restored.

In addition to the harm to victims described above, wrongdoers can realize powerful gains. Gig economy firms can achieve network effects, multi-level marketing distributors can recruit more distributors to increase their "downline," and for-profit colleges can plow federal aid dollars back into marketing to recruit more students. Orders that simply require wrongdoers to return their direct profits are unlikely to deter these practices market-wide, and the result is that the Commission continues to target practices-false earnings claims in particular-that it has been battling for decades, only to see this same misconduct recur year after year. ${ }^{92}$

\section{Advantages of the Penalty Offense Authority under $\S 5(\mathrm{~m})(1)(\mathrm{B})$}

Section $5(\mathrm{~m})(1)(B)$ of the FTC Act-the Penalty Offense Authority-is a unique authority with unique requirements, and considerable promise. In this Part, we sketch out how the Commission originally used this authority to tackle market-wide harms, only to largely abandon it as the Agency shifted its focus to shutting down scams. We then detail three key advantages of the Penalty Offense Authority relative to $\S 13(\mathrm{~b})$ : more effective deterrence, lessened litigation risk, and greater market-wide impact.

\section{A. Background on the Penalty Offense Authority}

In the late 1960s and early 1970s, Congress and others became concerned that the FTC was addressing wrongful conduct through inadequate resolutions. The Commission's orders halted unfair or deceptive conduct, but violators did not forfeit profits or compensate victims. A landmark 1969 American Bar Association Report, for example, found serious inadequacies in

92 For example, more than 40 years ago, the Commission found that, in the for-profit college sector, the Agency's "case-by-case adjudication was not achieving the requisite prophylactic effect." FTC, PROPRIETARY Vocational and HOME STUdy SCHOOls: Final REPORT TO THE FEDERAL TRADE COMMISSION AND PROPOSED TRADE REGULATION RULE (16 CFR PART 438), at 19 (1976), https://files.eric.ed.gov/fulltext/ED134790.pdf [https://perma.cc/SE2Z-XBTH]. History has borne this out. Four years after that report was issued, the Commission sued Bell \& Howell Company, then the parent of DeVry, for misleading students about their likelihood of obtaining employment after graduation. See Bell \& Howell Co., 95 F.T.C. 761,762 (1980) (describing in its complaint that DeVry had been marketing resident training and home study courses with misleading claims about employment prospects). Decades later, the Commission charged the same school with the same misconduct. See Press Release, FTC, DeVry University Agrees to $\$ 100$ Million Settlement with FTC (Dec. 15, 2016), https://www.ftc.gov/news-events/press-releases/2016/12/devryuniversity-agrees-100-million-settlement-ftc [https://perma.cc/SE2Z-XBTH]. 
the FTC's consumer enforcement program, ${ }^{93}$ findings that echoed those of another influential report by Ralph Nader. ${ }^{94}$ The Commission's no-money cease-and-desist orders were harshly criticized. Robert Pitofsky, the FTC's future Chairman, referred to these orders as "scandalously weak." 95 Congress also found these orders inadequate. Senator Warren Magnuson called them "a slap of the violator's wrist," 96 and Representative John E. Moss argued that they were "clearly inadequate" when rules have been violated. ${ }^{97}$ In 1975, this dissatisfaction contributed to the enactment of the Magnuson-Moss Warranty Act. ${ }^{98}$

In addition to reaffirming the Commission's rulemaking powers, the Magnuson-Moss Act gave the Commission extensive new authorities to seek redress for consumers and civil penalties against persons who violate FTC rules or who knowingly engage in practices that the FTC has previously determined were unfair or deceptive. This final authority is codified in $\S$ $5(\mathrm{~m})(1)(\mathrm{B})$ of the FTC Act, the Penalty Offense Authority. ${ }^{99}$

93 See ABA, REPORT of the ABA COMMission TO STUDy THE FEDERAL TRADE COMMISSION 1 (1969) (finding that the FTC had mismanaged its resources and showed a downward trend in virtually all categories analyzed).

94 See generally EDWARD COX, ROBERT FELLMETH \& JOHN SCHULZ, THE CONSUMER AND THE FEDERAL Trade COMmission: A CRitique of the Consumer PROTECTION RECORD OF THE FTC (1969).

95 Irving Scher, Gerald P. Norton, Caswell O. Hobbs, III, Robert Pitofsky \& Victor H. Kramer, Part II-FTC Improvement Act, 45 ANTITRUST L.J. 96, 117 (1976). Pitofsky continued: "Businessmen engaged in fraudulent practices knew in advance that the worst that could happen to them in most cases would be that if a fraud were detected, and if the Commission decided to proceed against that company as opposed to hundreds of other companies engaged in similar practices, and if the complaint ever proceeded to a conclusion, they would then be asked to discontinue the practice. In effect, the most significant deterrent to engaging in fraudulent practices in those days was the considerable lawyers' fees that would be generated by a Commission investigation." Id.

96119 CONG. REC. 29,480 (1973) (statement of Sen. Warren Magnuson). "A mere cease-anddesist order," Sen. Magnuson added, "has frequently let a wrongdoer keep his ill-gotten gains." Id.

97 120 CONG. REC. 31,735 (1974) (statement of Rep. John E. Moss). Representative Robert C. Eckhardt added that the Administration was committed to making "consumer fraud pursuable, punishable, and profitless," and that the Commission needed expanded authority to ensure this. 120 CONG. REC. 31,735 (1974) (statement of Rep. Robert C. Eckhardt).

98 See generally Beales \& Muris, supra note 70, at 8-21 (describing the legislative history).

99 As noted, $\S 5(\mathrm{~m})(1)(\mathrm{B})$ was added to the FTC Act by section 205 of the Magnuson-Moss Warranty-FTC Improvement Act. Pub. L. No. 93-637, 88 Stat. 2183 (1975). In 1994, §5(m)(1)(B) was amended to clarify that defendants could challenge de novo the FTC's underlying determination that a practice was unfair or deception. Federal Trade Commission Act Amendments of 1994, Pub. L. No. 103-312, 108 Stat 1691 (1994). 
Under the Penalty Offense Authority, the Commission can seek civil penalties against violators of Commission orders if:

- The Commission has issued a final cease and desist order, other than a consent order, following an administrative proceeding under $\S 5$ (b) of the FTC Act; 100 and

- The Commission has determined in that order that a particular practice is unfair or deceptive and therefore unlawful;101 and

- A party has engaged in that practice after the Commission's cease-and-desist order became final, with actual knowledge that the practice is unfair or deceptive. ${ }^{102}$

In other words, when parties are on notice that the Commission has condemned certain practices in a litigated final order, ${ }^{103}$ these practices can become "penalty offenses"-offenses that carry with them the threat of significant civil penalties. ${ }^{104}$

The Penalty Offense Authority does not detail how actual knowledge can be established. In certain instances, actual knowledge can potentially be imputed based on admissions or other evidence.105 However, one unambiguous way to trigger penalty liability is to apprise parties of the Commission's prior determinations, which then exposes them to penalty liability if they engage in similar practices. These practices then become penalty offenses with respect to those on notice.

Importantly, there is no statute of limitations on previous Commission findings. That is, even if the Commission determined decades ago that a practice is deceptive, that practice can become a penalty offense for companies on notice of the Commission's determination, regardless of when the determination was made. 106

The Penalty Offense Authority includes particularly strong due process protections for defendants. First and most significantly, parties cannot be held liable unless they are shown to have had actual knowledge of the

10015 U.S.C. $\S 45(b)$.

101 Id.

10215 U.S.C. $\S 45(\mathrm{~m})(1)(\mathrm{B})$.

103 A default order may also trigger liability under $\S 5(\mathrm{~m})(1)(\mathrm{B})$.

104 When the Commission seeks civil penalties, both parties have the right to demand a jury to determine whether a violation has occurred. See United States v. J. B. Williams Co., 498 F.2d 414, 423-30 (2d Cir. 1974) (noting that the defendant had the right to have a jury summoned and summarizing many cases that had reached similar conclusions).

105 For example, we have seen entities under FTC investigation tout the fact that they are aware of previous FTC orders relating to the subject of the investigation. See, e.g., DIRECT SELLING AsSOC., LEGITIMATE DiRECT SELLING VS. ILlEGAL PYRAMID SCHEMES, https://www.dsa.org/ docs/default-source/ethics/internalconsumptionwhitepaper.pdf [https://perma.cc/Q 5 YF-9R4A].

106 See, e.g., FTC v. Sears, Roebuck \& Co., No. 81-503, 1983 WL 1889, at * 3 (D. Colo. Oct. 18, 1983) (stating that orders issued before the codification of $\S 5(\mathrm{~m})(1)(\mathrm{B})$ can trigger penalty liability). 
Commission's determination - the most exacting knowledge standard found anywhere in the FTC Act.107 In addition, even if actual knowledge can be shown, parties are entitled under the authority to a de novo hearing on any issues of fact, including on whether their conduct is sufficiently similar to that which was previously condemned.108 Finally, and exceptionally, defendants in penalty offense actions can challenge the Commission's prior determination that such conduct was unlawful, thereby forcing the Commission to both defend its prior determination and demonstrate that its findings can be applied to distinct facts. 109

As discussed further below, the Penalty Offense Authority has been used rarely over the last four decades. As a result, there is limited case law analyzing these due process protections. ${ }^{110}$ In our view, it is particularly important to ensure that any action under this section involves conduct that is sufficiently related to the prior conduct condemned by the Commission, and that this prior condemnation remains appropriate. ${ }^{111}$ However parties need not rely solely on prosecutorial discretion, as the authority's defendantfriendly protections provide strong guardrails against inappropriate use.

The addition of this tool to the FTC's arsenal was expected to have a significant impact. Miles Kirkpatrick, who led the ABA Committee that highlighted the ineffectiveness of the Commission in 1969, and who would later become the Agency's chairman, suggested that $\S 5(\mathrm{~m})(1)(\mathrm{B})$ be named the "instant penalty" section. ${ }^{112}$ Others described this new power as the Commission's "unsprung bear trap," and one commentator suggested that the Commission begin proactively incorporating the program into future administrative complaints. ${ }^{113}$

10715 U.S.C. $\S 45(\mathrm{~m})(1)(\mathrm{B})(2)$.

10815 U.S.C. $\S 45(\mathrm{~m})(2)$.

109 Id.

110 Two litigated decisions are worth noting. In 1982, a federal court rejected a challenge to the statute's constitutionality, while recognizing - this right was codified - that defendants can challenge the Commission's prior legal determinations. United States v. Allied Publishers Serv., Inc., 1982-83 Trade Cas. (CCH) I 64,983, at * 1 (E.D. Cal. 1982). In addition, in 1988, a federal court found that prior Commission orders could trigger penalties only if the Commission specifically determined that a practice was unfair or deceptive. United States v. Hopkins Dodge, Inc., 849 F.2d 311, 314 (8th Cir. 1988).

111 One of the few decisions analyzing this authority rejected the argument that the Commission's earlier determinations were overly broad to bind the defendants. In 1978, the Commission issued synopses stating that it was unlawful to "falsely represent the filling content of down products[,] ... affix false and inaccurate labels concerning the filling content of down products[, or] ... falsely represent in advertising, the filling contents of down products." Sears, Roebuck E Co., 1983 WL 1889, at * 3 . The court found that the practices condemned were sufficiently particular to bind the company. Id. at * 4 .

112 Miles W. Kirkpatrick, Introductory Remarks, Title II of the Magnuson-Moss WarrantyFederal Trade Commission Improvement Act, 44 ANTITRUST L.J. 509, 511-12 (1975).

113 Scher et al., supra note 95, at 113-15. 
After securing this new authority in 1975, the FTC began to deploy it. As detailed in internal Commission records, the Commission established a task force in 1975 to review its new authority and make recommendations on how to apply it. ${ }^{114}$ Of particular interest to the task force was how to establish that firms had "actual knowledge" that certain practices had been condemned by the Commission-a necessary predicate for establishing liability. ${ }^{115}$ The task force recommended that the Commission serve companies with a "synopsis" of applicable Commission case law, along with the cases themselves. ${ }^{116}$ While this notification is not a legal requirement, it was a clear way to establish knowledge, and the recommendation was accepted.117

In 1976, the Commission launched a pilot program in which it formally notified dozens of businesses about Agency orders declaring that specific practices were unlawful.118 The notices warned the corporate recipients that if they violated the terms of those orders, they could be subject to civil penalties.119 The Commission then conducted follow-up investigations to determine whether such firms continued to engage in unfair and deceptive practices, and in 1977, the Commission announced its first civil penalty actions under this program. ${ }^{120}$

During this period, according to internal records, Penalty Offense Authority notifications were disseminated to market participants in a number of industries, including auto rental, franchises, general business opportunities, and cosmetics. 121 The Commission also targeted marketing and advertising tactics, including door-to-door sales, endorsements, energy savings claims, and truth in lending. ${ }^{122}$

The Commission used the Penalty Offense Authority to target whole industries, problems in certain geographic areas, and the largest corporations of the era, such as Sears Roebuck.123 Within five years, according to internal records, the Commission had sent notifications to over 2000 firms.124 Commissioner Patricia Bailey, reflecting in 1982 on the Agency's early use of the authority, called it "an extremely effective and efficient way to enforce the

114 This is based on the authors' review of internal FTC memos that are in custody of the FTC.

$115 \mathrm{Id}$.

116 Id.

117 Id.

118 See David O. Bickart, Civil Penalties Under Section $5(m)$ of the Federal Trade Commission Act, 44 U. CHI. L. REV. 761,768 (1976) (describing the FTC's early use of their authority to enforce the civil penalty provisions).

119 Id.

120 Id.

121 See supra note 114 .

122 Id.

123 FTC v. Sears, Roebuck \& Co., No. 81-503, 1983 WL 1889, at * ${ }_{1}$ (D. Colo. Oct. 18, 1983).

124 See supra note 114 . 
law," and one that furthered the Commission's ability to protect "not only consumers, but also honest business." 125

Despite this early momentum, the use of the authority fell dramatically in the 1980 s. As noted earlier, the Commission shifted its priorities away from systemic market problems and toward small-time scams during this period, and $\S 13(\mathrm{~b})$ became the Agency favored tool to shut them down. ${ }^{126}$

Over the last decade, the Penalty Offense Authority has been used only once. In the late 2000s, the Commission began uncovering widespread deception around the sale of "bamboo" textile products that were in fact made of rayon. ${ }^{127}$ Bamboo is seen as environmentally friendly, while manufacturing rayon involves the use of harsh chemicals.128 Because rayon products are still functional, seeking relief for consumers under $\S 13(\mathrm{~b})$ may have been seen as difficult, and the Commission initially challenged this deception without seeking redress or disgorgement. ${ }^{129}$ Months later, however, the Commission changed course, dialing up its enforcement program by serving dozens of retailers with synopses of a previously litigated decision. ${ }^{130}$ That allowed the Commission, in 2013, to announce settlements with four major retailers that included civil penalties in addition to injunctive relief. 131

\section{B. Key Advantages of the Penalty Offense Authority over $\S 13(b)$}

Although the Commission has rarely deployed its Penalty Offense Authority, doing so can offer three key advantages over seeking monetary relief solely under $\S 13(\mathrm{~b})$. First, the Authority allows the Commission to seek

125 Federal Trade Commission Reauthorization: Hearing Before the Subcomm. on Com., Transp., E Tourism of the H. Comm. on Energy \& Com., 97th Cong. 138-39 (1982) (statement of Hon. Patricia P. Bailey, Comm'r, Federal Trade Commission) [hereinafter Testimony of Commissioner Patricia P. Bailey Before the H.R.].

126 See sources cited in supra note 3 and accompanying text.

127 See Press Release, FTC, FTC Warns 78 Retailers, Including Wal-Mart, Target, and Kmart, to Stop Labeling and Advertising Rayon Textile Products as "Bamboo" (Feb. 3, 2010), https://www.ftc.gov/news-events/press-releases/2010/02/ftc-warns-78-retailers-including-wal-marttarget-kmart-stop [https://perma.cc/NWJ5-S2 $\mathrm{QF}$ ] ("Seventy-eight companies nationwide have received Federal Trade Commission letters warning that they may be breaking the law by selling clothing and other textile products that are labeled and advertised as 'bamboo,' but actually are made of manufactured rayon fiber.").

128 Id.

129 See Press Release, FTC, FTC Charges Companies with 'Bamboo-zling' Consumers with False Product Claims (Aug. 11, 2009), https://www.ftc.gov/news-events/press-releases/2009/o8/ftccharges-companies-bamboo-zling-consumers-false-product-claims [https://perma.cc/KN8Y-9TCA] (announcing a no-money cease-and-desist order).

130 See Press Release, supra note 127.

131 Press Release, FTC, Four National Retailers Agree to Pay Penalties Totaling \$1.26 Million for Allegedly Falsely Labeling Textiles as Made of Bamboo, While They Actually Were Rayon (Jan. 3, 2013), https://www.ftc.gov/news-events/press-releases/2013/o1/four-national-retailers-agree-paypenalties-totaling-126-million [https://perma.cc/H4RK-8DAE]. 
civil penalties, which unlike equitable relief can be calibrated to actually deter wrongful conduct while promoting practices like self-reporting. Second, particularly given the challenges before the Supreme Court, the Penalty Offense Authority creates less litigation risk than 13 (b). Finally, the Authority is well suited to having a market-wide impact, which promotes widespread compliance and saves taxpayer resources. Each of these advantages is discussed in turn.

\section{Deterrence}

What distinguishes the Penalty Offense Authority from tools that authorize (or authorized) equitable monetary relief, like $\S 13(\mathrm{~b})$, is that the Penalty Offense Authority authorizes the Agency to seek civil penalties. Penalties offer a number of advantages over restitution or disgorgement available through $\S$ 13(b), particularly when it comes to effectuating general deterrence.

As discussed above, equitable relief under $\S 13$ (b) was awarded based on a fairly rigid formula, according to which an award generally could not exceed the amount directly lost by victims or earned by wrongdoers.132 This formula can underdeter serious wrongdoing, especially when the consequences of that wrongdoing are difficult to calculate, or far exceed direct losses or gains. In fact, the Supreme Court has indicated that punitive remedies are not available in equity. 133

Unlike equitable relief, civil penalties are, by their nature, punitive. They are intended not only to punish the wrongdoer but also to deter others from engaging in similar misconduct. ${ }^{134}$ Because the likelihood of being caught by a law enforcement agency is usually very low, basic deterrence theory indicates that penalties on those who are caught must be severe. As one economist put it, "[a] penalty intended to deter or influence economic behavior should, at a minimum, be designed to remove the economic benefit

132 See supra Part II.

133 See Liu v. SEC, 140 S. Ct. 1936, 1942 (2020) (explaining that relief that exceeds profits was not "typically available in equity" (internal quotation marks omitted)).

134 See United States v. ITT Cont'l Baking Co., 420 U.S. 223, 232 (1975) (finding that penalties under the FTC Act were intended to "provide a meaningful deterrence against violations"); see also Paul Rubin, The Economics of Regulating Deception, 10 CATO J. 667, 684 (1991) ("Policies should . . . be aimed at making sure that harmful acts do not pay."); Colin S. Diver, The Assessment and Mitigation of Civil Money Penalties by Federal Administrative Agencies, 79 CoLUM. L. REV. 1435, 1464 (1979) ("The penalty for violating a regulation serves as a surrogate 'cost' of production .... As such, its severity becomes as much a part of the rational calculus of the producer as any other cost, and the severity of regulatory fines will likely have significant motivational impact." (footnotes omitted)). 
of the illegal activity, taking into account the documented benefit and the likelihood of escaping detection." 135

Penalties can and should exceed ill-gotten gains. In a 2012 action against Google, for example, the Commission estimated that the penalties obtained (based on an alleged order violation) constituted more than five times the company's ill-gotten gains. ${ }^{136}$ Meanwhile, penalties that do not exceed (or even capture) ill-gotten gains are generally too lenient, in that they are unlikely to deter others from engaging in similar misconduct, especially when the likelihood of detection is low. ${ }^{137}$

In addition to deterring wrongful conduct more effectively than equitable relief, civil penalties can be calibrated to the severity of the misconduct.138 The FTC Act already lays out factors for courts to consider when ordering civil penalties. However, the Commission has never issued any interpretive rules or guidance, and these factors leave courts with considerable discretion. In contrast, many agencies explicitly outline when self-reporting of unlawful

135 Recommendations of the Administrative Conference of the United States, 44 Fed. Reg. 38,817, 38,825 (July 3, 1979); see also United States v. DISH Network LLC, 954 F.3d 970, 980 (noting that because many violations go undetected, penalties should constitute an "appropriate multiplier" of harm).

136 After the FTC's proposed settlement with Google was challenged in court as being inadequate, the Commission responded that "Google's penalty was many times over the upperbound of what the FTC estimates the company earned from the alleged violation." United States' Resp. to Consumer Watchdog's Amicus Curiae Br. at 9-10, United States v. Google, Inc., No. 3:1204177, 2012 WL 13080180 (N.D. Cal. Nov. 16, 2012).

137 Penalty judgments that do not exceed or even capture ill-gotten gains raise concerns. See, e.g., Dissenting Statement of Commissioner Rohit Chopra, Google LLC and YouTube, LLC, FTC File No. 1723083, 2019 WL 4256289 (F.T.C.), at *1 (Sept. 4, 2019), https://www.ftc.gov/system/files/documents/ public_statements/1542957/chopra_google_youtube_dissent.pdf [https://perma.cc/CMR $3-\mathrm{UQ}_{4} \mathrm{~L}$ ] (arguing that the civil penalty obtained against Google failed to capture revenue derived from the illegal surveillance of children); see also Statement of Commissioner Rohit Chopra, Speedway Motorsports, FTC File No. Xo10021, 2018 WL 3995652 (F.T.C.), at *1 (Aug. 10, 2018) [hereinafter Chopra, Speedway Motorsports], https://www.ftc.gov/system/files/documents/public_statements/1400510/x010021_oil_chem_speedway_rc_sta tement.pdf [https://perma.cc/QU99-BZ62] (arguing that the Commission should not allow defendants to profit from order violations).

138 Under 15 U.S.C. $\S 45(\mathrm{~m})(1)(\mathrm{C})$, courts are directed, in awarding civil penalties, to take into account "the degree of culpability, any history of prior such conduct, ability to pay, effect on ability to continue to do business, and such other matters as justice may require." That last factor in particular affords courts considerable discretion. 15 U.S.C. $\S 45(\mathrm{~m})(1)(\mathrm{A})$. 
conduct will be rewarded with a degree of leniency. ${ }^{139}$ Armed with civil penalty authority, the Commission can do the same.140

Notably, in addition to advancing deterrence, civil penalties can also further the goal of obtaining adequate equitable relief. When the Commission has a clear basis to seek civil penalties against a firm, it is well positioned to instead seek fulsome redress as part of a negotiated settlement, or to seek a combination of the two.

As noted earlier, a unique feature of civil penalty actions is that the Commission must refer complaints for civil penalties to the Attorney General to litigate the matter in the name of the United States. This has been successful. For example, in 2017, the Department of Justice litigated to a final judgment a civil penalty action against Dish Network. The judgment included $\$ 280$ million in civil penalties. ${ }^{141}$

This arrangement also allows the Department of Justice to evaluate the Commission's investigation for violations of other civil and criminal statutes. It can bring to bear the expertise of the appropriate federal prosecutor, such as the United States Attorney of a federal district, whose office may have unique insights into local markets where the conduct may have occurred.

Furthermore, the arrangement can help preserve FTC resources while also preserving its independence. If the Attorney General does not take action within 45 days of the civil penalty action referral, the Commission may file the complaint in its own name. ${ }^{142}$ In addition, the Attorney General will generally not settle any Commission referral without the Agency's assent. ${ }^{143}$

139 See, e.g., EPA's Audit Policy, EPA, https://www.epa.gov/compliance/epas-audit-policy [https://perma.cc/SB7P-TT3A]; Share Class Selection Disclosure Initiative, DIV. OF ENFORCEMENT, SEC, https://www.sec.gov/enforce/announcement/scsd-initiative [https://perma.cc/WM2Q-PAEP]; Responsible Business Conduct: Self-Policing, Self-Reporting, Remediation, and Cooperation, CFPB BULL. (June 25, 2013), https://files.consumerfinance.gov/f/201306_cfpb_bulletin_responsible-conduct.pdf [https://perma.cc/2X9A-KP 5 S (outlining the policies regarding self-reporting of unlawful conduct from the EPA, SEC, and CFPB, respectively). The FTC also provides guidance in certain contexts. For example, for companies that fail to comply with Hart-Scott-Rodino (HSR) reporting requirements, the FTC advises that they should remedy this failure as soon as possible, and provide an explanation of why the notification was not filed, when that failure was discovered, and what steps they have taken to prevent a future violation. Hart-Scott-Rodino Premerger Notification Program: What is the Premerger Notification Program?, FTC, 14 (Mar. 2009), https://www.ftc.gov/sites/default/ files/attachments/premerger-introductory-guides/guide1.pdf [https://perma.cc/BA7Y-CCGV].

140 Early in his tenure, then-Commissioner Chopra called on the Commission to do so. See Chopra, Speedway Motorsports, supra note 137.

141 Press Release, FTC, Court Orders \$280 Million from Dish Network, Largest Ever Do Not Call Penalty (June 8, 2017), https://www.ftc.gov/news-events/blogs/business-blog/2017/o6/courtorders-280-million-dish-network-largest-ever-do-not [https://perma.cc/7QXB-7RVJ].

14215 U.S.C. $\S 56(\mathrm{a})(1)$.

143 Section $5(\mathrm{~m})(1)(\mathrm{C})(3)$ authorizes the Commission to "compromise or settle any action for a civil penalty if such compromise or settlement is accompanied by a public statement of its reasons and is approved by the court." 15 U.S.C. $\S 45(\mathrm{~m})(1)(\mathrm{C})(3)$. 
If the Commission resurrects the use of the Penalty Offense Authority, the Agency should formalize an agreement between the Federal Trade Commission and the Attorney General that would help to mature and operationalize the existing referral process. It is important that the Federal Trade Commission and the Attorney General can share enforcement responsibilities in a predictable and orderly way.

\section{Lessened Litigation Risk}

In addition to increasing deterrence, deploying the Penalty Offense Authority can substantially reduce litigation risk for the Commission relative to cases seeking equitable relief, such as those brought under any successor to $\S 13(\mathrm{~b})$. As noted, even before $A M G$, seeking restitution or disgorgement presents risks when it comes to calculating harm. ${ }^{144}$ Pursuing equitable monetary relief generally requires the Commission to estimate consumer harm or ill-gotten gains - an estimation that a defendant can, of course, try to rebut. This means that even in cases of clear wrongdoing, if the harm is difficult to quantify, well-heeled defendants can, at a minimum, make the pursuit of monetary relief risky, expensive, and time consuming.

In contrast to its authority to seek equitable monetary relief, nothing in the existing case law or the FTC Act suggests these penalties should be limited to a rigid calculation of direct loss. On the contrary, victims' losses or wrongdoers' gains are not among the listed statutory factors for calibrating civil penalties. ${ }^{145}$

By invoking $\S 13(\mathrm{~b})$-even in its diminished form-in addition to the Penalty Offense Authority, the Commission can also seek injunctive relief through penalty actions. Section 13(b) expressly authorizes courts to issue injunctions, and it can be invoked by the Commission whenever it has reason to believe that the law is being broken. As such, any conceivable case under a penalty offense strategy would also be actionable under $\S 13(\mathrm{~b})$, meaning the Commission could plead under both authorities, and seek both injunctive relief and civil penalties. ${ }^{146}$

144 See supra Part II.

145 See 15 U.S.C. $\S 45(\mathrm{~m})(1)(\mathrm{C})$ (laying out the civil penalty factors for violations). The Chairman of the Commission has made clear that harm should not be a ceiling on penalties. See Statement of Chairman Joseph J. Simons, FTC v. Hyperbeard Inc., FTC File. No. 1923109, 2020 WL 3073324 (F.T.C.), at * ${ }_{1}$ (June 4, 2020), https://www.ftc.gov/system/files/documents/public _statements/1576438/192_3109_hyperbeard_-_statement_of_chairman_simons.pdf

[https://perma.cc/G7 9 -DKQB] (expressing disagreement with the Commissioner's view that civil money penalties start with harm).

146 Although the FTC's core ability to seek injunctions under $\S 13(\mathrm{~b})$ is not under challenge, there have been challenges to the Commission's ability to obtain injunctions when misconduct has ceased. See FTC v. Shire ViroPharma, Inc., 917 F.3d 147, 150 (rejecting the FTC's extension of $\S$ 
To be clear, utilizing the Penalty Offense Authority does not eliminate the Commission's litigation risks. As noted, the authority affords defendants exceptionally strong due process protections. However, what this tool can eliminate is the gamesmanship that has plagued efforts to calculate harm or ill-gotten gains down to a penny, with any uncertainty accruing to the benefit of wrongdoers. Under the Penalty Offense Authority, the merits of any individual case can be disputed aggressively, but the Agency's power to seek remedies that actually deter is beyond dispute.

\section{Market-wide Impact}

The Penalty Offense Authority is well suited to have market-wide impact. By serving notice of a Commission determination on firms across an industry-while making clear that the determination is binding, enforceable, and backed by civil penalties - the Commission can correct market-wide illegal practices. In fact, because civil penalties are available through the Penalty Offense Authority-as they are for rulemaking-this changes the calculus for firms in ways that increase compliance, while reducing the need to bring enforcement actions for similar conduct over and over again. Notably, in the early years of the program, most companies that received penalty offense notifications appear to have come into compliance voluntarily. ${ }^{147}$

The Penalty Offense Authority is also flexible, affording the Commission discretion to deploy the authority strategically in certain industries or during certain times. For example, during the present pandemic, the FTC recently invoked its authority under $\S 5(\mathrm{~m})(1)(\mathrm{B})$ to warn marketers of diabetes treatments that they could face civil penalties for deceptive claims. ${ }^{148}$

To be clear, we do not believe a penalty offense program is a substitute for deploying other tools in the Commission's arsenal, such as rulemaking, that can also help promote compliance market-wide. We believe that dusting off these tools is vital to not only protecting consumers but also effectively stewarding the Agency's scarce resources. As detailed throughout this Article, there are certain practices-such as income misrepresentations-that the

13(b)'s reach). However, since actions under the Penalty Offense Authority would requiring a showing that companies knowingly broke the law, this hurdle is unlikely to impede the program, as the Commission would be able to show that the conduct is either ongoing or likely to recur, absent an injunction.

147 According to Commissioner Patricia Bailey, the Commission's early use of $\S 5(\mathrm{~m})(1)(\mathrm{B})$ resulted in a "high level of voluntary compliance achieved quickly and at a low cost." Testimony of Commissioner Patricia P. Bailey Before the H.R., supra note 125, at 138-39.

148 Press Release, FTC, FTC Sends Cease and Desist Demands to 10 Companies Suspected of Making Diabetes Treatment Claims Without the Required Scientific Evidence (Sept. 9, 2021), https://www.ftc.gov/news-events/press-releases/2021/og/ftc-sends-cease-desist-demands-10companies-suspected-making [https://perma.cc/T4ZQ-8GCL]. 
Commission has been battling through case-by-case enforcement for decades, without any appreciable impact on compliance. This raises questions about whether the Agency's status quo approach represents an efficient use of taxpayer resources, and it suggests that deploying additional tools could increase the Agency's effectiveness.

\section{Potential Applications of the Penalty Offense Authority}

Section 13(b) was a critical tool for the Commission, but even before $A M G$, it was not always the Agency's strongest tool. To assess where it would be beneficial to deploy the Penalty Offense Authority, the Commission should look to the following three criteria: (1) where a harmful practice has been condemned in a Commission order, but is not forbidden by rule; (2) where it is feasible that major market participants are or could be placed on notice of the penalty offense; and (3) where the FTC's traditional enforcement program underdeters this wrongdoing, either because equitable relief is difficult to measure or because it is insufficient to remedy and deter harms.

We have identified five areas where the Commission could designate penalty offenses based on existing orders: for-profit college fraud, false earnings claims targeting workers, online disinformation, deceptive data harvesting, and illegal targeted marketing. Each area is discussed in turn.

\section{A. For-Profit College Fraud}

For-profit colleges market themselves as offering prospective students a fast track to rewarding careers, but this marketing often involves misrepresentations that violate the FTC Act. Although its engagement in this area has varied over time, the Commission has been targeting deceptive practices in this industry since the 1920 . ${ }^{149}$ In 1976, following an extensive study of the for-profit school sector, the Commission found widespread problems including high-pressure sales tactics, false claims of selectivity, and "an appalling lack of substantiation for the job and earnings claims that are made." 150 The Report further found that the industry was failing to comply

149 We thank Muriel Kenfield-Kelleher, who examined the FTC's enforcement history in this space through her participation in Harvard Law School's Project on Predatory Student Lending, for vital contributions to this Section, including by identifying two FTC enforcement actions from 1925 . See F.W. Dobe, 8 F.T.C. 383 , 384, 390 (1925) (holding that the advertising at issue constituted unfair methods of competition); Civ. Serv. Sch., Inc., 22 F.T.C. 471, 473 (1925) (same). During this period, deceptive practices by for-profit colleges were charged as being unfair methods of competition.

150 See FTC, PROPRIETARY VOCATIONAL AND HOME STUDY SCHOOLS: FINAL REP. TO THE Fed. TRade Comm'N and PROPOSEd Trade REgulation Rule (16 CFR ParT 438), at 385 (1976), https://files.eric.ed.gov/fulltext/ED13479o.pdf [https://perma.cc/M9WD-UWZJ]. 
with the Commission's voluntary guides, and that "case-by-case adjudication was not achieving the requisite prophylactic effect." 151

Although the Commission initiated a rulemaking in the 1970 s to combat these harmful practices, it abandoned these efforts as part of the broader deregulatory dismantling of the Agency in the $1980 \mathrm{os},{ }^{152}$ and returned to the enforcement approach that the Commission itself had deemed a failure.

The last few decades have laid bare the problems with the FTC's handsoff approach to for-profit colleges. In the 2000s, for-profit enrollment and defaults surged, and a comprehensive Senate report showed that many of the problems highlighted by the FTC in the 1970s had only worsened. ${ }^{153}$ Veterans returning from Iraq and Afghanistan faced particularly problematic recruitment, as publicly traded companies like DeVry, Corinthian Colleges, University of Phoenix, and Career Education Corporation took in billions in veterans' benefits. 154

Yet the FTC largely stood idle during the worst years of for-profit predation after the financial crisis, bringing no major cases, even as state attorneys general and the new Consumer Financial Protection Bureau filed multiple lawsuits against major market players. 155 The FTC finally took a significant action with a settlement in 2016 against DeVry, using its authority

151 Id. at 2. The Report also quoted the Washington Post, which weighed in that "the FTC's investigations have been necessarily tedious, its proceedings ponderous, and its penalties limited." $I d$. at $2-3$.

152 In 1980, the Second Circuit vacated the Commission's proposed rule on the ground that the Commission failed to define with specificity the practices determined to be unfair and deceptive, among other grounds cited. Katherine Gibbs Sch. v. FTC, 612 F.2d 658, 662 (2d Cir. 1980). The Agency could have corrected these deficiencies, but it declined to do so.

153 See generally STAFF OF S. COMM. ON HEALTH, EdUC., LAB., \& PENSIONS, 112TH CONG., For PROFIT HighER EDUCATION: THE FAILURE TO SAFEGUARD THE FEDERAL INVESTMENT AND ENSURE STUDENT SUCCESS (Comm. Print 2012).

154 Veterans Educ. Success, Why For-Profit Schools are TARgeting Veterans EDUCATION BENEFITS 10 (2014), https://vetsedsuccess.org/why-for-profit-institutions-are-targetingveterans-education-benefits [https://perma.cc/P6RW-3GHT].

155 See, e.g., Press Release, CFPB, CFPB Sues For-Profit Corinthian Colleges for Predatory Lending Scheme (Sept. 16, 2014), https://www.consumerfinance.gov/about-us/newsroom/cfpb-sues-forprofit-corinthian-colleges-for-predatory-lending-scheme [https://perma.cc/Q8V4-6YS7]; Press Release, Off. of the N.Y. Att'y Gen., A.G. Schneiderman Announces Groundbreaking \$10.25 Million Dollar Settlement With For-Profit Education Company That Inflated Job Placement Rates To Attract Students (Aug. 19, 2013), https://ag.ny.gov/press-release/2013/ag-schneiderman-announces-groundbreaking-1025million-dollar-settlement-profit [https://perma.cc/4YXM-CS 35 ; Press Release, Ill. Att'y Gen., Madigan Sues National For-Profit College (Jan. 18, 2012), https://www.illinoisattorneygeneral.gov/ pressroom/2012_01/20120118.html [https://perma.cc/66VW-SQBC]. 
under $\S 13(\mathrm{~b}) .156$ The Commission's 2019 settlement with the University of Phoenix was also brought under 13(b).157

Although the Commission has sought and obtained equitable monetary relief in these recent actions against for-profit schools, the incentive to mislead prospective students-especially veterans-is overwhelming. Recruiting a single student can easily earn a school tens of thousands of dollars in taxpayer funded tuition dollars, and because of a regulatory loophole, recruiting veterans is even more remunerative, as every dollar in tuition collected through military benefits allows schools to collect nine dollars in other federal funds. ${ }^{158}$ It is no surprise that in its recent action against University of Phoenix, the FTC charged that veterans were targeted with misrepresentations. 159

In light of the enormous potential to profit through deception, these FTC actions are unlikely to significantly deter ongoing or future for-profit fraud. For example, the FTC's recent order against University of Phoenix included $\$ 191$ million in relief-a large headline number, but only a fraction of the tuition the school collected from students targeted by its deceptive ads. ${ }^{160}$ As

156 See Press Release, FTC, DeVry University Agrees to $\$ 100$ Million Settlement with FTC (Dec. 15, 2016), https://www.ftc.gov/news-events/press-releases/2016/12/devry-university-agrees100-million-settlement-ftc [https://perma.cc/SE2Z-XBTH].

157 Press Release, FTC, FTC Obtains Record \$191 Million Settlement from University of Phoenix to Resolve FTC Charges It Used Deceptive Advertising to Attract Prospective Students (Dec. 10, 2019), https://www.ftc.gov/news-events/press-releases/2019/12/ftc-obtains-record-191-millionsettlement-university-phoenix [https://perma.cc/SN2P-GMXA].

158 More than two decades ago, through the so-called 90/10 rule, Congress capped the percentage of revenue that for-profit schools can earn from U.S. Department of Education programs at ninety percent. See 20 U.S.C. $\S 1094(a)(24)$ ("In the case of a proprietary institution of higher education . . . , such institution will derive not less than ten percent of such institution's revenues from sources other than funds [as statutorily allowed]."). This was a market test designed to ensure programs would meet quality standards that would attract students paying out of pocket. Many bad actors found a loophole and instead decided to engage in predatory recruiting of those with federal military benefits. See What is the 90/10 Loophole?, VETERANS EDUC. SUCCESS, https://veteranseducationsuccess.org/90-10-loophole [https://perma.cc/M3ZX-6QGG] (describing the aggressive and deceptive marketing and recruiting tactics used by for-profit colleges targeted at service members and veterans).

159 Complaint for Permanent Injunction and Other Equitable Relief 9 ा 52-54, FTC v. Univ. of Phoenix, No. 2:19-05772 (D. Ariz. Dec. 10, 2019), https://www.ftc.gov/system/files/documents/ cases/university_of_phoenix_ftc_v_uop_complaint_signed.pdf [https://perma.cc/S7WB-DC $3 Z$ ].

160 See id. at \11 ("[University of Phoenix] has charged consumers tuition ranging from about $\$ 7,400$ to $\$ 19,400$ per year, depending on the program."); Press Release, FTC, FTC Sends Nearly $\$ 50$ Million in Refunds to University of Phoenix Students (Mar. 24, 2021), https://www.ftc.gov/newsevents/press-releases/2021/03/ftc-sends-nearly-50-million-refunds-university-phoenix-students [https://perma.cc/DYF7-AY83] (reporting that FTC refunded 147,000 students which means that the average refund was $\$ 340$ per student); see also Press Release, FTC, FTC Obtains Record $\$ 191$ Million Settlement from University of Phoenix to Resolve FTC Charges It Used Deceptive Advertising to Attract Prospective Students (Dec. 9, 2015), https://www.ftc.gov/news-events/press-releases/2019/12/ftcobtains-record-191-million-settlement-university-phoenix [https://perma.cc/GKV4-3MEA]. 
to the students themselves, the harm they suffered likely far exceeds what the Commission can provide in refunds. Their tuition alone is far greater than what they will receive, and this does not even take into account the collateral consequences of for-profit fraud-thousands in interest payments, defaults that increase the cost of credit, collections that send borrowers' bank accounts into the red, and other harms, including opportunity costs.

These deficiencies underscore some of the key drawbacks-regardless of whether $\S 13(b)$ is restored-in seeking equitable relief alone in complex cases of corporate fraud. First, in litigation, approximating harm experienced by tens of thousands of students can be challenging, especially against deeppocketed institutions. Certain students may not have enrolled but for the misrepresentations, suggesting full redress (and more) is appropriate, while others may have suffered lesser harms. ${ }^{161}$ Second, even a robust order would likely be insufficient to deter the conduct, given the overwhelming recruitment incentives described earlier.

Activating penalties in addition to equitable relief could materially change this incentive structure, while providing more fulsome relief to students. Penalties in a case involving thousands of students can quickly escalate and can wipe out a school's illegal earnings and more. The prospect of facing civil penalties, which survive bankruptcy reorganizations, could therefore be a substantial deterrent against a lawbreaking, and a counterweight to the economic incentives to lie.

Using existing orders, the Commission can act swiftly to ensure schools are on notice that certain common practices are penalty offenses. For example, in 1959, the Commission determined that it was deceptive to make false claims around the urgency of enrollment, selectivity, accreditation, or postgraduation earnings, 162 and many of these findings were repeated in subsequent orders.163 Of course, these practices continue to permeate the sector decades later. ${ }^{164}$

The Commission should also inventory its prior orders to determine whether other misrepresentations-such as misrepresenting transferability of credit-have also been conclusively determined to be illegal. Accreditors and state agencies can be enlisted to assist in this strategy, including by providing

161 In our experience, almost all students enrolling in career colleges are, in fact, doing so based on promises of gainful employment, but there is at least a theoretical possibility that some may be enrolling for other reasons.

162 Nw. Air Coll., Inc., 55 F.T.C. 712, 714-15 (1959).

163 See E. Detective Acad., Inc., 78 F.T.C. 1428, 1461 (1971) (finding it was deceptive to make false earnings claims); Macmillan, Inc., 96 F.T.C. 208, 298 (1980) (finding it was misleading to make false earnings and selectivity claims).

164 See Staff OF S. COMM. ON Health, EdUC., LAB., \& Pensions, supra note 153, at 1-10 (finding widespread misrepresentations in the for-profit college sector, including around accreditation and job placement rate). 
formal notifications on their own. This strategy could significantly strengthen the FTC's ability to combat widespread illegal deception by for-profit colleges.

\section{B. False Earnings Claims Targeting Workers}

The for-profit school sector is just one of many industries that lure victims in with lies about potential earnings. For decades, the FTC has been battling firms that pitch "business opportunities" by making false claims about the amount of money participants can earn. The problem of false earnings claims is widespread, so much so that the Commission retains two rules-the Franchise Rule and Business Opportunity Rule-expressly designed to regulate these claims. 165 But these rules generally do not cover two major components of the economy: multilevel marketers and gig economy employers, like rideshare and food delivery services. ${ }^{166}$ In both of these areas, the Commission can significantly step up its deterrence by implementing a penalty offense program.

Multilevel marketing is a business model where individual distributors are recruited to both sell products to family and friends and enlist others to become distributors. Under certain circumstances, the Commission regards these firms as constituting an illegal pyramid scheme.

The Commission's Koscot decision in 1975 established the key test for when a multilevel marketing operation constitutes an illegal pyramid scheme.167 Essentially, when a company compensates distributors based on recruitment rather than actual sales, this indicates the company is operating as an illegal pyramid scheme. ${ }^{168}$ Relevant here, the Commission also found in Koscot that it was deceptive to mislead prospective recruits about how much income they could earn. 169

Forty-five years after Koscot, the Commission continues to rely on its findings to battle firms it believes are operating illegally. Between 2018 and 2020, the Commission brought two actions against alleged pyramid schemesNerium (now known as Neora) and Advocare.170 In the latter case, the

165 See 16 C.F.R. $\S 436$ (Franchise Rule); 16 C.F.R. $\S 437$ (Business Opportunity Rule).

166 See sources cited supra note 165.

167 Koscot Interplanetary, Inc., 86 F.T.C. 1106, 1180 (1975).

168 The decision found that pyramid schemes are "characterized by the payment by participants of money to the company in return for which they receive (1) the right to sell a product and (2) the right to receive in return for recruiting other participants into the program rewards which are unrelated to the sale of the product to ultimate users." Id.

169 Id. at 1134-36.

170 Press Release, FTC, FTC Sues Multi-Level Marketer Neora, Formerly Known as Nerium, Alleging It Operates as an Illegal Pyramid Scheme (Nov. 1, 2019) [hereinafter Press Release, FTC Sues Multi-Level Marketer Neora], https:/www.ftc.gov/news-events/press-releases/2019/11/ftc-suesmulti-level-marketer-neora-formerly-known-nerium [https://perma.cc/ECT3-2UPN]; Press Release, FTC, Multi-Level Marketer AdvoCare Will Pay \$150 Million to Settle FTC Charges It Operated an 
Commission successfully shut down the alleged pyramid structure entirely; the former is in litigation as of this writing. ${ }^{171}$ In both cases, in addition to being charged with operating an illegal pyramid scheme, the companies were charged with misleading recruits about prospective earnings. ${ }^{172}$

As shown in these recent actions, $\S 13$ (b) was at times a useful tool to check pyramid schemes and, ideally, return funds to victims. In cases like Advocare, for example, the Commission relied on the authority to recover millions in ill-gotten gains while obtaining injunctive relief to halt the alleged scheme. The Commission is seeking significant relief against Nerium as well.

But while this approach has yielded some successes, it also carries serious drawbacks. Determining whether a multilevel marketing operation qualifies as an illegal pyramid scheme requires resource intensive investigations that can last years. During this time, more victims will likely suffer, while owners and top distributors can dissipate assets. Furthermore, the structure and size of a multilevel marketing operation can change considerably during this period, which can complicate litigation should the FTC decide to sue. Finally, if the FTC does sue, litigation can drag on for years as experts battle over whether the structure of the business is illegal. Altogether, it is not clear that the Commission's current enforcement approach is adequately deterring the most pernicious pyramid schemes, which continue to emerge year after year despite decades of FTC warnings. ${ }^{173}$ And whatever advantages this enforcement approach offered were largely eliminated by the decision in $A M G .174$

In the past, the FTC considered a different approach to this problem, but decided not to pursue it. In 2006, the Commission proposed to expand the coverage of its existing Business Opportunity Rule to require multilevel marketers to provide accurate earnings disclosures to potential recruits or face civil penalties for their failure to do so. ${ }^{175}$ In its Notice of Proposed Rulemaking, the Commission observed that false earnings claims are "not uncommon," are key to recruiting distributors, and have been challenged in more than twenty FTC actions from 1990 to 2006.176 However, the MLM

Illegal Pyramid Scheme (Oct. 2, 2019) [hereinafter Press Release, AdvoCare], https://www.ftc.gov/ news-events/press-releases/2019/10/multi-level-marketer-advocare-will-pay-15o-million-settle-ftc [https://perma.cc/ECT $3-2 \mathrm{UPN}]$.

171 Press Release, Advocare supra note 170.

172 Id.; Press Release, FTC Sues Multi-Level Marketer Neora, supra note 170.

173 That is, while 13 (b) enforcement actions can-often after many years-shut down an individual scheme, the pace of the process and the lack of penalty authority make it unlikely that these actions effectuate sufficient general deterrence.

174 See supra Introduction.

175 Business Opportunity Rule, 71 Fed. Reg. 19,054, 19,067-70 (proposed Apr. 12, 2006) (final rule codified at 16 C.F.R. $\S 437$ ).

176 See id. at 19,060 (listing FTC actions challenging deceptive earnings claims and noting "pyramid schemes often deceive consumers with the promise of large potential incomes"). 
industry fiercely objected to being bound by this rule, and the FTC agreed to generally exclude multilevel marketers from its coverage. ${ }^{177}$ At least until recently, the FTC has taken the position that case-by-case enforcement under $\S 13$ (b) has been an effective strategy. 178

The Commission should reconsider its approach to this problem. While it is reasonable to debate whether rules requiring specific disclosures will reduce the harmful consequences of deception, there is no debate that the problem those disclosures were designed to correct-false earnings claims-is widespread and illegal. Yet this problem persists year after year. For example, early in the COVID-19 pandemic, the Commission sent warning letters to nine multilevel marketing firms allegedly making false earnings claims. ${ }^{179}$

These warnings could be significantly more effective if they included notice of penalty offenses. There are numerous final, litigated orders in which the Commission has determined that deceptive practices by multilevel marketing companies are unlawful under $\S 5 .{ }^{180}$ If these orders were served on major multilevel marketers today, they would be on notice that they face substantial civil penalties for engaging in any of the prohibited conduct.

For example, numerous litigated orders condemn the practice of misleading potential recruits about the income they can earn. ${ }^{181}$ Serving notice of the Commission's determination on this issue alone would make clear that false earnings claims constitute a penalty offense. Doing so could offer a number of advantages for the Commission's enforcement program. ${ }^{182}$

177 See Business Opportunity Rule, 76 Fed. Reg. 76,816, 76,818 (Dec. 8, 2011) (codified at 16 C.F.R. § 437) (stating that the Commission decided to narrow the scope of the rule after having received more than 17,000 comments from the MLM industry, which argued that it was unfair to apply the rule to legitimate MLMs).

178 See Business Guidance Concerning Multi-level Marketing, FTC, https://www.ftc.gov/tipsadvice/business-center/guidance/business-guidance-concerning-multi-level-marketing [https://perma.cc/JWY9-G $55 \mathrm{H}$ ] (arguing that, when it comes to MLM oversight, case-by-case enforcement "can offer significant benefits when compared with prescriptive rulemaking or legislative action").

179 Press Release, FTC, FTC Sends Warning Letters to Multi-Level Marketers Regarding Health and Earnings Claims They or Their Participants are Making Related to Coronavirus (Apr. 24, 2020), https://www.ftc.gov/news-events/press-releases/2020/04/ftc-sends-warning-letters-multilevel-marketers-regarding-health [https://perma.cc/Y $\left.{ }_{5} \mathrm{WP}-\mathrm{F}_{2} \mathrm{BE}\right]$.

180 See, e.g., Koscot Interplanetary, Inc., 86 F.T.C. 1106 (1975); Holiday Magic, Inc., 84 F.T.C. 748 (1974); Amway Corp., Inc., 93 F.T.C. 618 (1979); Nat'l Dynamics Corp., 82 F.T.C. 488 (1973), aff'd in part and rev 'd. in part, 492 F.2d 1333 (2d Cir. 1974), cert. denied 419 U.S. 993 (1974), reissued, 85 F.T.C. 391 (1976).

181 See sources cited supra note 180 and accompanying text.

182 In our experience, multilevel marketing firms are already deeply familiar with the Commission's history in this area, particularly with decisions like Koscot. As such, while serving notice of these orders certainly makes sense, it is likely the Commission could show actual knowledge even without one. 
First, designating income misrepresentations as a penalty offense has potential to deter one of the most problematic yet ubiquitous features of this industry: false promises of rich profits, which is what lures so many recruits. Second, it would give the Commission additional tools to correct and deter violations: if operators ignore warnings, the Commission could launch a full investigation to determine if an operator is a pyramid, and then seek both injunctions through $\S 13$ (b) and civil penalties. Or, it could pursue a narrower approach that targets the income misrepresentations, which may allow it to obtain meaningful relief much more expeditiously than a full blown pyramid prosecution. ${ }^{183}$

Importantly, this strategy can be replicated in other areas where companies make false earnings claims to recruit participants. For example, a growing number of Americans earn their living through the so-called gig economy, and the FTC has already accused one of the biggest players in the space of misrepresenting income that workers can expect to earn. ${ }^{184}$

Restitution or disgorgement is a poor remedy for this type of fraud. First, working in the gig economy can impose significant opportunity costs, meaning that the harm to workers can far exceed the gap between what they earn and what they were promised, which is how restitution would likely be calculated. Second, gig economy firms can realize huge benefits from deceptive income claims, as recruiting workers can make their services more valuable, yielding network effects that can lock in a firm's dominance. ${ }^{185}$

Similar to in the pyramid context, the Commission has held repeatedly for decades that using inflated earnings claims to recruit workers or distributors is a deceptive practice under the FTC Act. In fact, there was a series of litigated orders targeting sales outfits like Encyclopedia Britannicaone of the "gig" employers of its day.186 In the order against Britannica, for example, the Commission found that that " $\mathrm{t}]$ here is obvious deception where

183 There is precedent for the Commission targeting alleged income misrepresentations by multilevel marketers, rather than their structure. See, e.g., Press Release, FTC, FTC Action Halts MOBE, a Massive Internet Business Coaching Scheme (June 11, 2018), https://www.ftc.gov/newsevents/press-releases/2018/06/ftc-action-halts-mobe-massive-internet-business-coaching-scheme [https://perma.cc/XV2D-XP87].

184 See Press Release, FTC, \$20 Million FTC Settlement Requires Uber to Have Proof for Earnings, Auto Financing Claims (Jan. 19, 2017), https://www.ftc.gov/news-events/blogs/business-blog/2017/01/20million-ftc-settlement-requires-uber-have-proof-earnings [https://perma.cc/L $3 \mathrm{~T}_{2}-\mathrm{YX}_{44}$ ].

185 In addition, recruiting gig workers based on false earnings claim can have supply side effects, in that recruiting additional workers can reduce their compensation.

186 Encyclopedia Britannica, Inc., 87 F.T.C. 421, 485-89 (1976), aff'd, 605 F.2d 964 (7th Cir. 1979), cert. denied, 445 U.S. 934 (1980), modified, 100 F.T.C. 500 (1982); see also Nat'l Dynamics Corp., 82 F.T.C. 488, 563-66 (1973) (prohibiting income misrepresentations), aff'd and remanded on other grounds, 492 F.2d 1333 (2d Cir.), cert. denied, 419 U.S. 993 (1974), reissued, 85 F.T.C. 391 (1976). 
respondent misrepresents the type of position being offered and the amount of compensation that will be guaranteed." 187

The Commission should take steps to make clear that recruiting gig workers based on false earnings claims is a penalty offense under the FTC Act. Once platforms have knowledge of Britannica or similar orders, misleading prospective workers comes with liability for penalties that can far exceed whatever gains they hope to realize from deceit. 188 These firms already deny gig workers the protections that traditional workers enjoy, such as sick leave and wage-and-hour restrictions. These failures are compounded by the failure to deliver earnings as advertised. Gig workers should be able to avoid wasting their time on a bad bargain. 189

\section{Online Disinformation}

The Commission's overreliance on $\S 13$ (b) has also hampered its efforts to tackle fake review and influencer fraud, as well as other deceptive disinformation campaigns online.

According to one estimate, companies spent $\$ 2.42$ billion on advertising through social media influencers in 2019, which is projected to increase to $\$ 4.14$ billion by 2022.190 Facebook's Instagram and Google's YouTube are major vehicles for influencer advertising campaigns. Individuals with a significant following can often generate major fees for posts and videos that promote a product or brand. Unsurprisingly, fake likes, fake followers, and fake reviews are now polluting the digital economy, making it difficult for families and small businesses looking for truthful information. ${ }^{191}$

These fake reviews can have a huge impact on sales. A highly cited study estimated that a one-star rating increase on Yelp translated to an increase of five to nine percent in revenues for a restaurant. ${ }^{192}$ Another study found that a one-

187 Encyclopedia Britannica, Inc., 87 F.T.C at 487.

188 As noted, formal notification is not a necessary predicate to seeking penalties under the Penalty Offense Authority, and it is likely that a well-publicized program could place firms on notice even if they have not received a formal notice or warning.

189 A similar strategy could be adopted in the franchise industry, where there are widespread reports of illegal income misrepresentations to potential franchisees. Although misrepresentations are generally prohibited by the Franchise Rule, the Rule does not directly cover entities like franchise consultants, who are often responsible for the most egregious misrepresentations.

190 David Cohen, eMarketer Sees 33.6\% Jump in US Influencer Marketing Spend in 2021, ADWEEK (July 20 2021), https://www.adweek.com/social-marketing/emarketer-sees-33-6-jump-in-us-influencermarketing-spend-in-2021 [https://perma.cc/24DA- $\mathrm{Z}_{3} \mathrm{C} 7$ ].

191 Rebecca Dolan, Have Online Reviews Lost All Value?, WALL ST. J. (Sept. 27, 2019, 1:49 PM), https://www.wsj.com/articles/have-online-reviews-lost-all-value-11569606584 [https://perma.cc/PZZ6-4GZ8].

192 Michael Luca, Reviews, Reputation, and Revenue: The Case of Yelp.com 1 (Harv. Bus. Sch. Working Paper No. 12-016, 2016), https:/www.hbs.edu/faculty/Publication\%2oFiles/12-016_a7e4a5a 2-03f9-49od-bo93-8f951238dba2.pdf [https://perma.cc/8QBG-H7NH]. 
point boost in a hotel's online ratings at sites like Travelocity and TripAdvisor is tied to an eleven percent jump in room rates, on average. ${ }^{193}$ There is also a growing body of research suggesting that early, positive signals can even create a herd effect, leading many more consumers to purchase a product. ${ }^{194}$

In addition to distorting sales in otherwise legitimate markets, fake reviews have also been weaponized by counterfeiters. As detailed in a comprehensive report by the Government Accountability Office, counterfeiters are using pseudonymous reviews to boost their fake products, harming honest firms that are forced to compete with those operating unlawfully. ${ }^{195}$

Despite the substantial distortion caused by fake reviews fraud, the Commission has opted to pursue no-money settlements that do little to deter the practice. In the 2019 Sunday Riley matter, the Commission charged that the founder and chief executive officer of a successful cosmetics brand was personally ordering her employees to write fake reviews, while giving them instructions on how to evade detection. 196 The scheme was ongoing for more than two years, and many of these reviews appear to have been written to smear competitors and otherwise give Sunday Riley an unfair advantage. ${ }^{197}$ In spite of the egregiousness of these allegations, the Commission resolved its investigation with a settlement that simply ordered the company not to repeat its lawbreaking. ${ }^{198}$

193 Chris Anderson, CTR. FOR HOSP. Rsch., THE IMPACT OF SOCIAL MEdiA ON LODGING PERFORMANCE 11 (2012), https:/ecommons.cornell.edu/bitstream/handle/1813/71194/ Anderson_202012_20The_20impact_20of_20social_2omedia.pdf?sequence=1\&isAllowed=y [https://perma.cc/S9D8-8ELU].

194 See, e.g., Georgios Askalidis \& Edward C. Malthouse, The Value of Online Customer Reviews, 16 RECSYS 155, 155 (2016) ("[T] he conversion rate of a product can increase by as much as $270 \%$ as it accumulates reviews . . . . with the first five reviews driving the bulk of the aforementioned increase" and that "the existence of reviews provides valuable signals to the customers, increasing their propensity to purchase"); Lev Muchnik, Sinan Aral \& Sean J. Taylor, Social Influence Bias: $A$ Randomized Experiment, 341 SCI. 647, 648-49 (2013) (finding that, for a given product, a single initial positive "upvote" creates an accumulating herd effect that results in a twenty-five percent higher average rating for that item at the end of a five month observation window compared to an initial negative "down-vote").

195 See U.S. GOV't AcCOUNTABILITy OFF., GAO-18-216, InTELlectual Property: AGENCIES CAN IMPROVE EFFORTS TO ADDRESS RISKS POSED BY CHANGING COUNTERFEITS MARKET 11 (2018), https://www.gao.gov/assets/69o/689713.pdf [https://perma.cc/JTL8-EHT9] ("When selling online, counterfeiters may post pictures of authentic goods on the websites where they are selling counterfeits and may post pseudonymous reviews of their products or businesses in order to appear legitimate.").

196 Complaint 9 ๆ 8-13, Sunday Riley Modern Skincare, LLC, FTC File No. 1923008, 2019 WL 5783865 (F.T.C.) (Oct. 21, 2019) [hereinafter Sunday Riley Complaint], https://www.ftc.gov/system/ files/documents/cases/192_3008_sunday_riley_complaint_o.pdf [https://perma.cc/3PWB-ZHEV].

197 Sunday Riley Statement, supra note 81.

198 See Sunday Riley Modern Skincare, LLC, FTC File No. 1923008, 2019 WL 5419395 (F.T.C.), at ${ }^{*} 2$ (Oct. 21, 2019), https://www.ftc.gov/system/files/documents/cases/192_3008_c4729_ sunday_riley_order.pdf [https://perma.cc/JLW5-6GCL]. 
The Commission's overreliance on $\S 13(\mathrm{~b})$ also hamstrung its approach to companies that launder advertising through high-priced influencers. The Commission has sent warning letters to dozens of influencers who fail to disclose their material connections to sellers, ${ }^{199}$ but a third-party analysis conducted by nonprofit organization Truth in Advertising suggests that many ignored the Commission's warnings. 200

For both fake reviews and advertising laundered through influencers, deploying the Penalty Offense Authority offers substantial benefits over the Commission's historic approach. Forty years ago, the Commission issued an order in Cliffdale Associates finding that it was deceptive to portray endorsements as objective when in fact they were written by the seller's paid employees or contractors. ${ }^{201}$ This is the exact theory the Commission pursued against Sunday Riley to condemn fake reviews,202 and is likewise the theory the Agency has deployed against influencers who fail to disclose material connections. ${ }^{203}$ If the Commission or another party notified major advertisers about conduct condemned in the Cliffdale order, it would expose these parties to civil penalty liability for some of the most common forms of digital deception, including fake reviews and undisclosed influencer payments. In Sunday Riley, this would have meant real relief for cheated customers and real deterrence against fake review fraud.

Designating the failure to disclose material connections as a penalty offense is long overdue. In the current environment, firms are under huge pressure to generate fake reviews or otherwise engage in deceptive "organic" advertising. The upside can be huge, and because the practices are so widespread, many believe they will be put at a competitive disadvantage if they do not engage in the same practices. ${ }^{204}$ At the same time, the vast majority of wrongdoers likely will not be caught, underscoring the

199 Press Release, FTC, CSGO Lotto Owners Settle FTC's First-Ever Complaint Against Individual Social Media Influencers (Sept. 7, 2017), https://www.ftc.gov/news-events/press-releases/ 2017/09/csgo-lotto-owners-settle-ftcs-first-ever-complaint-against [https://perma.cc/69VV-YSRY].

200 See Shana Mueller, TINA.org Files FTC Complaint Against Instagram Influencers, GLOBENEWSWIRE (Mar. 5, 2020, 7:00 PM), https://www.globenewswire.com/news-release/2019/ 03/05/1747874/o/en/TINA-org-Files-FTC-Complaint-Against-Instagram-Influencers.html [https://perma.cc/ $73 \mathrm{WW}-\mathrm{AQKN}]$ (finding that more than ninety percent of recent warning letter recipients continue to flout the law).

201 Cliffdale Assocs., Inc., 103 F.T.C. 110, 110 (1984).

202 Sunday Riley Complaint, supra note 196.

203 See, e.g., Complaint ๆ 17-20, FTC v. Teami, LLC, No. 8:20-518 (M.D. Fla. Mar. 5, 2020), https://www.ftc.gov/system/files/documents/cases/complaint_4.pdf [https://perma.cc/Y68F-KERV].

204 As explained by one leading e-commerce consultant, "incentives are incredibly high for brands to create fake reviews or incentivize reviews," and many brands feel "if I don't do this, then I'm not staying level with my competition, I'm literally just falling behind." Sapna Maheshwari, When Is a Star Not Always a Star? When It's an Online Review, N.Y. TIMES (Nov. 28, 2019), https://www.nytimes.com/2019/11/28/ business/online-reviews-fake.html [https://perma.cc/298C-MKR6]. 
importance of steep penalties for those who are. Given this incentive structure, we do not believe the Commission's historic reliance on no-money orders (or on settlements that disgorge ill-gotten gains with no penalty) is adequate, especially when the Agency has the authority to exact real penalties on those who break the law.

Disinformation is polluting our digital markets, harming both consumers and honest firms. Tackling this problem will require stepped up enforcement both by major platforms, which can benefit from these illegal practices, ${ }^{205}$ and the Commission. Rather than waiting for Congress or counting on selfpolicing by major platforms, the FTC should do its part by using its existing authority to pursue penalties against those who break the law.206

\section{Deceptive Data Harvesting}

In the absence of a general federal data protection law, the FTC has historically relied on its deception authority to police privacy practices.207 This means that in typical Commission privacy actions, the misconduct alleged involves not how a company uses consumers' information, but rather whether such uses accord with a company's representations.

Section 13 (b), even before $A M G$, was poorly suited to bringing cases in this area. Those companies with the most aggressive data harvesting practices often do not charge consumers for their services, meaning that restitutionwhich is limited to direct consumer loss-is not usually a viable theory for seeking monetary relief. As to disgorgement, while there is no question that unlawful data harvesting can enrich firms, these gains can be difficult to quantify. Even if the Commission was able to develop a reasonable estimate

205 Past statements have detailed how platforms stand to profit from the spread of disinformation. See Statement of Commissioner Rohit Chopra, Regarding the Endorsement Guides Review, FTC File No. P204500, 2020 WL 763449 (F.T.C.), at *1 (Feb. 12, 2020) [hereinafter Statement Regarding the Endorsement Guides Review], https://www.ftc.gov/system/files/ documents/public_statements/1566445/p204500-endorsement_guides_reg_review-chopra_stmt.pdf [https://perma.cc/9PM9-JVTF] ("Advertisers and social media platforms are seeking big returns from influencer marketing, which can allow paid advertising to seem more authentic."); Statement of Commissioner Rohit Chopra Regarding the Report to Congress on Social Media Bots and Deceptive Advertising, FTC File No. P204503, 2020 WL 4049775 (F.T.C.), at *1 (July 16, 2020), https://www.ftc.gov/system/files/documents/public_statements/1578231/social_bots_chopra_stateme nt.pdf [https://perma.cc/C $348-\mathrm{KPSR}$ ] ("Unfortunately, false, fraudulent, and inflammatory content leads to higher levels of engagement.").

206 The Commission's guidelines in our nonbinding Endorsement Guides could also be codified into a rule, which would trigger civil penalties for all violators with actual or constructive knowledge of the rule. See Statement Regarding the Endorsement Guides Review, supra note 205, at *3.

207 See, e.g., Press Release, FTC, Mobile Advertising Network InMobi Settles FTC Charges It Tracked Hundreds of Millions of Consumers' Locations Without Permission (June 22, 2016), https://www.ftc.gov/news-events/press-releases/2016/o6/mobile-advertising-network-inmobisettles-ftc-charges-it-tracked [https://perma.cc/3S68-3 W2J]. 
of illegal gains, this was unlikely to deter other firms from engaging in similar practices, especially if these practices can help entrench their dominance.

Recent history has borne this out. In 2011, the FTC reached a settlement with Google for misleading users about the company's privacy practices. ${ }^{208}$ Likely owing to the perceived difficulty of calculating disgorgement, the Commission settled the case administratively for $\$ 0$. The following year, the FTC reached a settlement with Facebook after alleging similarly deceptive practices, and again settled the matter for $\$ 0.209$ These firms likely realized massive gains through the information they illegally harvested from users, yet they paid nothing.

Designating privacy misrepresentations as a penalty offense would alter this landscape. Companies that lie to users about privacy practices would face stiff penalties, rather than a slap-on-the-wrist \$O warning. ${ }^{210}$ By sending penalty offense notifications to major tech companies and other harvesters of consumer data, the FTC can make clear that cheating users out of their data will come at a cost.

The Commission should inventory its existing orders to determine whether privacy misrepresentations have been previously condemned. Candidates already exist. For example, in a recent order against Cambridge Analytica, the Commission found that it was deceptive for the firm to misrepresent the types of information it was collecting from users.211 Similarly, in a decades-old order, the Commission found it was deceptive to collect consumers' sensitive information for one purpose, only to use it for

208 Press Release, FTC, FTC Charges Deceptive Privacy Practices in Googles Rollout of Its Buzz Social Network (Mar. 30, 2011), https://www.ftc.gov/news-events/press-releases/2011/o3/ftccharges-deceptive-privacy-practices-googles-rollout-its-buzz [https://perma.cc/5EUL-NWET].

209 Press Release, FTC, FTC Approves Final Settlement With Facebook (Aug. 10, 2012), https://www.ftc.gov/news-events/press-releases/2012/o8/ftc-approves-final-settlement-facebook [https://perma.cc/Y $32 \mathrm{U}-\mathrm{AE} 96]$.

210 Notably, after the FTC reached administrative settlements with Facebook and Google, both companies became liable for civil penalties for any violations. See 15 U.S.C. $\S 45(l)$. Yet in both cases, the prospect of FTC penalties was evidently insufficient to deter further misconduct: the FTC would later charge both firms with serious order violations. See Press Release, FTC, Google Will Pay \$22.5 Million to Settle FTC Charges It Misrepresented Privacy Assurances to Users of Apple's Safari Internet Browser (Aug. 9, 2012), https://www.ftc.gov/news-events/press-releases/2012/o8/google-will-pay-225-millionsettle-ftc-charges-it-misrepresented [https://perma.cc/HV 5 A-2SCJ]; Press Release, FTC, FTC Imposes $\$ 5$ Billion Penalty and Sweeping New Privacy Restrictions on Facebook (July 24, 2019) https://www.ftc.gov/news-events/press-releases/2019/07/ftc-imposes-5-billion-penalty-sweeping-newprivacy-restrictions [https://perma.cc/SZL8-VL85]. This suggests that the Commission should reassess how it is calibrating civil penalties, given the massive gains that deception can produce.

211 Cambridge Analytica, LLC, No. 9383, 2019 WL 6724446, at *10-11 (Nov. 25, 2019), https://www.ftc.gov/system/files/documents/cases/do9389_comm_final_opinionpublic.pdf [https://perma.cc/6SSD-MLFS] (finding it was deceptive under the FTC Act to misrepresent that an app did not collect personally identifiable information from users). The FTC also found it was deceptive for a firm to misrepresent its participation in the US-EU Privacy Shield program, another practice the Commission can designate as a penalty offense. Id. 
another purpose without alerting them. ${ }^{212}$ Depending on the facts, these findings could have applicability across the digital economy. ${ }^{213}$

Illegal data harvesting undermines privacy, entrenches digital dominance, and can endanger national security when information is compromised. The Commission must do more to deter these practices, and the Penalty Offense Authority could be a vital complement to other efforts that the FTC should undertake. ${ }^{214}$

\section{E. Illegal Targeted Marketing}

Social media platforms earn almost all of their revenue by building detailed dossiers on users that can then be deployed to target advertising to individual consumers. 215 For example, Facebook-which earns nearly all of its revenue from advertisers - touts its ability to target individual users based on their "behaviors" and "interests," as well as its ability to match an advertiser's existing customer base to users meeting a similar profile, the so-called Lookalike Audience feature.216 Facebook gathers this information through surreptitious surveillance of users' activities on the platform.

212 Beneficial Corp., 86 F.T.C. 119, 168-77 (1975) (finding that it was deceptive for a tax preparation firm to use consumers' tax information for marketing purposes without their consent).

213 For example, in 2019, the FTC charged Facebook with collecting users' phone numbers for purposes of enabling two-factor authentication, only to use their phone numbers for marketing. Complaint Iा 5-6, United States v. Facebook, Inc., No. 19-02184 (D.D.C. July 24, 2019), https://www.ftc.gov/system/files/documents/cases/182_3109_facebook_complaint_filed_7-24-19.pdf [https://perma.cc/8JKD-S6SX].

214 In connection with a report prepared for Congress, then-Commissioner Chopra proposed numerous improvements to the FTC's privacy and data security program. Statement Regarding the Rep. to Cong. on Privacy and Security, supra note 29.

215 See, e.g., Facebook Inc., Annual Report (Form 10-K) 7 (Jan. 28, 2021), https://d18rnop2 5nwr6d.cloudfront.net/CIK-0001326801/5fc46b22-5cb5-4014-bcb7-7edc64f2d963.pdf

[https://perma.cc/45D6-PTQ3] ("We generate substantially all of our revenue from selling advertising placements to marketers. Our ads enable marketers to reach people based on a variety of factors including age, gender, location, interests, and behaviors. Marketers purchase ads that can appear in multiple places including on Facebook, Instagram, Messenger, and third-party applications and websites.").

216 Business Help Center: Your Guide to Digital Advertising, FACEBOOK, https://www.facebook.com/ business/help/1029863103720320?id=802745156580214 (last visited Sept. 28, 2021). 
"Targeted" or "behavioral" advertising raises a host of consumer protection and competition concerns, including privacy, ${ }^{217}$ discrimination,, 218 fraud,, 219 and unfair competition.220 Relevant here, however, is whether these practices implicate the Fair Credit Reporting Act (FCRA), which dictates that consumer reports can be sold only for certain permissible purposes.221 While the Consumer Financial Protection Bureau is the primary enforcer of the FCRA, the FTC also can enforce the statute for a subset of covered entities, and any violations of its requirements are illegal under the FTC Act.222

Historically, the Commission has deployed this authority to ensure that consumer reports are not sold for purposes that are illegal under the FCRA. For example, in the 1980s, TransUnion launched a "target marketing" division that used data collected in its consumer reporting business to develop marketing lists that were then sold to third parties.223 In a progenitor to

217 See Dissenting Statement of Commissioner Rohit Chopra, Facebook, Inc., FTC File No. 1823109, 2019 WL 3386452 (F.T.C.), at *3 (July 24, 2019), https://www.ftc.gov/system/files/ documents/public_statements/1536911/chopra_dissenting_statement_on_facebook_7-24-19.pdf [https://perma.cc/S2 $\mathrm{P}_{5}$-LT9J] (stating Facebook's practices violated people's privacy).

218 See Dep't. of Hous. \& Urb. Dev. v. Facebook, Inc., FHEO No. 01-18-0323-8, at 3 (Mar. 28, 2019) (Charge of Discrimination), https://www.hud.gov/sites/dfiles/Main/documents/HUD_v_Facebook.pdf [https://perma.cc/WN7D-T86H] (stating that the way Facebook designed its advertising platform led to housing advertisements being targeted in discriminatory ways).

219 See Kelsey Sutton, Facebook Hid Inflated Video Ad Metrics Error for Over a Year, Advertisers Allege, ADWEEK (Oct. 17, 2018), https://www.adweek.com/digital/facebook-hid-inflated-video-admetrics-error-for-over-a-year-advertisers-allege [https://perma.cc/4KVU-66ZT] (stating Facebook intentionally overstated average watch times on paid video ads).

220 See Patience Haggin \& Kara Dapena, Google's Ad Dominance Explained in Three Charts, THE WALL ST. J. (June 17, 2019, 5:30 AM), https://www.wsj.com/articles/why-googles-advertisingdominance-is-drawing-antitrust-scrutiny-11560763800 [https://perma.cc/4KVU-66ZT] (explaining how Google's ad services are anticompetitive).

221 Under the FCRA, a "consumer report" is:

any written, oral, or other communication of any information by a consumer reporting agency bearing on a consumer's credit worthiness, credit standing, credit capacity, character, general reputation, personal characteristics, or mode of living which is used or expected to be used or collected in whole or in part for the purpose of serving as a factor in establishing the consumer's eligibility for [credit, insurance, employment or government license].

15 U.S.C. $\S 1681 \mathrm{a}(\mathrm{d})$. A consumer reporting agency, in turn, is defined as:

any person which, for monetary fees, dues, or on a cooperative nonprofit basis, regularly engages in whole or in part in the practice of assembling or evaluating consumer credit information or other information on consumers for the purpose of furnishing consumer reports to third parties, and which uses any means or facility of interstate commerce for the purpose of preparing or furnishing consumer reports.

15 U.S.C. $\S 1681 \mathrm{a}(\mathrm{f})$. The FCRA defines "permissible purposes" at 15 U.S.C. $\S 1681 \mathrm{~b}$.

222 See 15 U.S.C. $\S 1681 \mathrm{~s}(\mathrm{a})(1)$ ("[C]ompliance with the requirements imposed under this subchapter shall be enforced under the Federal Trade Commission Act.").

223 Trans Union Corp. v. FTC, 81 F.3d 228, 234 (D.C. Cir. 1996). 
contemporary targeted advertising practices, TransUnion compiled targeted lists of consumers by fitting them into profiles like "empty nesters" or "suburban elite," based on information the company compiled through its consumer reporting business. ${ }^{224}$ The FTC alleged that these lists constituted consumer reports, which can be sold only for permissible purposes. 225

The FTC's litigation against TransUnion lasted nearly a decade, and out of it emerged two key findings. First, in 1994, the Commission found that TransUnion's "target marketing" was not a permissible purpose under the FCRA for which consumer reports can be furnished,226 a finding later affirmed by the D.C. Circuit. 227 Second, in 2000 , the Commission found that TransUnion's marketing lists constituted consumer reports, as the "information disclosed through these products is the type of information that is 'used' and/or 'expected to be used' in whole or in part for the purpose of serving as a factor in establishing a consumer's eligibility for credit."228

The Commission's findings may have implications for social media platforms and other firms that sell access to lists of consumers based on attributes they share, if these attributes are used to make decisions around credit, housing, or employment. For example, the CFPB has been exploring whether aggregators of financial data are covered by the FCRA.229 Similarly, scholars and advocates are raising questions as to whether tech platforms may be acting as consumer reporting agencies, ${ }^{230}$ including if platforms develop

224 See id. at 229 (describing reports).

225 Trans Union Corp., 116 F.T.C. 1334, 1349-54 (1993).

226 Trans Union Corp., 118 F.T.C. 821, 869-70 (1994), rev'd in part and remanded by Trans Union Corp. v. FTC, 81 F.3d 228 (D.C. Cir. 1996).

227 See Trans Union Corp., 81 F.3d at 234 (affirming that target marketing was not a permissible purpose but remanding the case to the Commission to resolve whether Transunion's lists constituted consumer reports).

228 See Trans Union Corp., FTC No. 9255, 2000 WL 257766, at *12 (Feb. 10, 2000).

229 See CFPB, BUREAU SYMP.: CONSUMER ACCESS TO FinANCIAL RECORDS 6 (2020), https://files.consumerfinance.gov/f/documents/cfpb_bureau-symposium-consumer-access-financialrecords_report.pdf [https://perma.cc/NKD9-3CRH] ("Participants disagreed about whether or in what circumstances the Fair Credit Reporting Act (FCRA) applies or should apply to credit-related uses of permissioned data."); Press Release, CFPB, CFPB Announces Plan to Issue ANPR on ConsumerAuthorized Access to Financial Data (July 24, 2020), https://www.consumerfinance.gov/aboutus/newsroom/cfpb-anpr-consumer-authorized-access-financial-data [https://perma.cc/ZNE3-B74J].

230 See, e.g., Ed Mierzwinski \& Jeff Chester, Selling Consumers Not Lists: The New World of Digital Decision-Making and the Role of the Fair Credit Reporting Act, 46 SUFFOLK U. L. REV. 845, 860 (2013) ("The next question for the FTC involves whether new credit-scoring models on the Internet may cross a moving or blurry line, and become actionable under the FCRA."); Adam Levitin, Facebook: the New Credit Reporting Agency?, CREDIT SLIPS (Aug. 22, 2018, 11:39 PM), https://www.creditslips.org/creditslips/2018/08/facebook-the-new-credit-reporting-agency.html [https://perma.cc/V67K-QHEM] ('It's not clear if this is just a system for internal use or if users' trustworthiness scores are for sale to third parties, but if the latter, then would sure seem that Facebook is a Consumer Reporting Agency and subject to CRA provisions of the Fair Credit Reporting Act (FCRA)."); Complaint and Request for Investigation, Injunction and Other Relief 
"trustworthiness" scores of their users, ${ }^{231}$ or if they offer "lookalike" or "similar" audiences for creditors, landlords, or employers.

Platforms' advertising practices remain opaque, and more needs to be done to gain visibility into them. However, as the Commission examines these practices more closely, it may conclude that the FCRA is implicated, particularly if certain platforms are developing user profiles that are being furnished to third-party marketers. ${ }^{232}$ If so, it will be important to apprise these platforms of the fact that targeted marketing is not a permissible purpose under the FCRA. In doing so, the Commission can deploy its Penalty Offense Authority to complement its existing authorities under the FCRA.

Serving notice of the Commission's findings in TransUnion would allow the Commission to establish that the use of consumer reports for targeted marketing or other impermissible purposes is a penalty offense under the FTC Act, in addition to being banned by the FCRA. Although the TransUnion order did not explicitly find that the company's FCRA violations constituted unfair or deceptive practices, the FCRA already states this explicitly,233 meaning that a finding that conduct violates the FCRA is also a finding that such conduct was unfair or deceptive.234

In the Matter of Airbnb, Inc. ๆ $82-88$ (FTC Feb. 26, 2020), https://epic.org/privacy/ftc/airbnb/ EPIC_FTC_Airbnb_Complaint_Feb2020.pdf [https://perma.cc/L659-22ZT] (arguing that FCRA applies to Airbnb).

231 See Elizabeth Dwoskin, Facebook Is Rating the Trustworthiness of Its Users on a Scale from Zero to 1, WASH. POST. (Aug. 21, 2018), https://www.washingtonpost.com/technology/2018/o8/21/facebook-israting-trustworthiness-its-users-scale-zero-one [https://perma.cc/9QF8-4R6F] (explaining Facebook's trustworthiness score); Karl Brode, Airbnb Has Secret 'Trustworthy Scores' and This Privacy Group Is Demanding to See Them, VICE: MOTHERBOARD (Feb. 27, 2020, 12:55 PM), https://www.vice.com/ en_us/article/4ag7vq/airbnb-has-secret-trustworthy-scores-and-this-privacy-group-is-demanding-to-seethem [https://perma.cc/HWZ5-3SVK] (same).

232 These profiles would constitute consumer reports if they (1) bear on a consumer's "credit worthiness, credit standing, credit capacity, character, general reputation, personal characteristics, or mode of living" and (2) are "used or expected to be used or collected in whole or in part" to serve as a factor in determining credit, employment, or housing eligibility. 15 U.S.C. $§ 1681 \mathrm{a}(\mathrm{d})(1)$. Although the FCRA excludes from the definition of consumer report any "report containing information solely as to transactions or experiences between the consumer and the person making the report," 15 U.S.C. $\S 1681 \mathrm{a}(\mathrm{d})(2)(\mathrm{A})(\mathrm{i})$, many platforms scrape data from users' mobile devices, web browsing, and third-party apps and services.

233 Under 15 U.S.C. $§ 1681 \mathrm{~s}(\mathrm{a})(1)$, "a violation of any requirement or prohibition imposed under this subchapter shall constitute an unfair or deceptive act or practice in commerce, in violation of section 5(a) of the Federal Trade Commission Act [15 U.S.C. $\S 45$ (a)]." 15 U.S.C. $\S 1681$ s(a)(1).

234 Importantly, this distinguishes the FCRA from TILA, violations of which do not necessarily constitute unfair or deceptive practices. See United States v. Hopkins Dodge Sales, Inc., 849 F.2d 311, 314 (8th Cir. 1988) (holding that the Commission needed to make a specific finding that TILA violations were unfair or deceptive for that finding to bind other market participants pursuant to $\S 5(\mathrm{~m})(1)(B)$ ); Reliable Mortg. Corp., 113 F.T.C. 816, 819 (1990) (following Hopkins Dodge, contrasting TILA with the FCRA, which "specifically provide[s] that a violation constitutes an unfair or deceptive practice"). 
Although the Commission can already seek civil penalties through the FCRA, a strategy that incorporates the Penalty Offense Authority offers a major advantage. The maximum civil penalty for penalty offenses is more than ten times greater than what is available through the FCRA alone. 235 When it comes to holding tech behemoths accountable for harm to consumers and fair competition, the Commission must use every tool in its toolbox.

\section{CONCLUSION}

Deploying the Penalty Offense Authority should be part of a broader strategy to resurrect the FTC as a vigorous check against corporate malfeasance. This Article has detailed how the authority can be used to notice whole industries of unlawful practices, and to seek remedies that not only reverse the effects of wrongdoing but also deter others from crossing the line. We have identified five areas where the Commission has already condemned practices that can be designated as penalty offenses. Going forward, as the Commission condemns new forms of misconductparticularly around facial recognition, dark patterns, and other emerging harms - we believe it should include in its orders clear findings that can be served on other market participants.

In addition to increasing the Agency's ability to deter and correct wrongdoing, resurrecting the Penalty Offense Authority would mitigate the ongoing gamesmanship around $\S 13(\mathrm{~b})$, showing the marketplace that the FTC has more than one trick up its sleeve, regardless of $A M G$.

The Commission's overwhelming reliance on $\S 13(b)$ is of recent vintage. In the 1970s, following widespread dissatisfaction with "scandalously weak" no-money orders, ${ }^{236}$ Congress armed the Commission with strong tools to meaningfully deter widespread lawbreaking. These tools include rulemaking powers backed by civil penalties, the ability to seek damages under $\S 19$, and the Penalty Offense Authority described here. However, these powers were largely abandoned after James C. Miller III took over the FTC in 1981, as the Commission shifted its focus to halting scams using $\S 13$ (b).

The takeover and subsequent gutting of the Federal Trade Commission by Chairman Miller is an underappreciated milestone in our nation's

235 See Adjustments to Civil Penalty Amounts, 85 Fed. Reg. 2003, 2014-15 (codified at 16 C.F.R. pt. 1) (Jan. 14, 2020) (announcing inflation-adjusted civil penalties of $\$ 4,063$ under FCRA, and $\$ 43,280$ under $\S 5(\mathrm{~m})(1)(B))$. This disparity is appropriate, as liability under the Penalty Offense Authority requires a showing of actual knowledge.

236 Scher et al., supra note 95, at 117. 
economic history.237 By shifting attention and resources away from scrutinizing emerging business practices that pose harm to households and honest businesses, Miller and his lieutenants architected a new paradigm for corporate oversight. The FTC abandoned its former role and began to duplicate the role of criminal law enforcers who tackle fraud rings, but without the authority to seek any criminal sanctions. The Commission's new emphasis on shutting down "illegitimate" businesses created the guise of an active Agency, when, in reality, it became increasingly irrelevant to commercial regulation across many sectors of the economy.

Since the Miller era, the Commission has essentially ceded its role as the government's analytical engine of emerging commercial practices. The result has too often been an Agency that is disconnected from pressing market problems. In recent decades, the Commission has failed to tackle some of the worst abuses facing consumers, ranging from subprime mortgage lending to predatory for-profit colleges. By 2010, as Congress stripped key authorities from the Commission, industries actively lobbied to remain under FTC jurisdiction, 238 an effort currently being replicated by tech titans in the privacy arena. ${ }^{239}$ This does not reflect well on the Agency's credibility as a watchdog.

For the architects of this ideological project to weaken the FTC, the crisis around $\S 13$ (b) could prove to be the most striking blow yet. They have long argued that $\S 13$ (b) should be used only in cases involving "true fraudsters," 240 and there are now aggressive efforts to impose these limits by law, as part of any "fix" to $\S 13(\mathrm{~b}) .{ }^{241}$ Should they succeed, this would represent the culmination of their decades long project to defang this once-storied Agency, conceived of by Louis Brandeis to be a strong check on corporate power.

But if the FTC is rendered toothless, this is by choice. The Agency can shed its self-inflicted paralysis by deploying a broader set of tools to meet its mission. By deploying these tools, the Commission can reemerge as a

237 Recent scholarship is shedding light on this moment, and in particular how many of the changes Miller sought were driven by well-funded corporate interests. See, e.g., Luke Herrine, The Folklore of Unfairness 96 N.Y.U. L. REV. 431 (2020).

238 Auto dealers were able to obtain a rare exclusion from coverage under the Consumer Financial Protection Act, remaining instead under FTC jurisdiction. 12 U.S.C. $§ 5519$ (d).

239 For example, last year, the industry's leading trade association argued that Congress should preempt state privacy laws in favor of a one-size-fits-all framework enforced by the FTC. See Michael Beckerman, Americans Will Pay a Price for State Privacy Laws, N.Y. TIMES (Oct. 14, 2019), https://www.nytimes.com/2019/10/14/opinion/state-privacy-laws.html [https://perma.cc/8QBWFVRH] ("A national privacy law would be stronger with unified, well-funded enforcement through the Federal Trade Commission.").

240 See Beales \& Muris, supra note 70, at 40. They further argued that the use of $\S 13(\mathrm{~b})$ to target "legitimate" national advertisers "is wrong as a matter of law, troubling as a matter of policy, and threatens to undermine the operation of the fraud program, which has proven critical to the FTC's consumer protection mission." Id. at 4 .

241 See generally id. (arguing for a more limited reading of the Commission's authority under $\S 13(\mathrm{~b})$ ). 
vigorous watchdog, detecting and deterring systemic harm instead of playing whack-a-mole against small scams. Adopting this approach is essential to regaining the public's confidence and realizing Brandeis's vision of an Agency that protects the public from abuse and misuse of corporate power. 
